San Jose State University

SJSU ScholarWorks

Master's Theses

Master's Theses and Graduate Research

1990

\title{
Parental care and diet of California gull (Larus californicus) chicks at Alviso, California
}

Ann Jennifer Dierks

San Jose State University

Follow this and additional works at: https://scholarworks.sjsu.edu/etd_theses

\section{Recommended Citation}

Dierks, Ann Jennifer, "Parental care and diet of California gull (Larus californicus) chicks at Alviso, California" (1990). Master's Theses. 43.

DOI: https://doi.org/10.31979/etd.8jut-qxxk

https://scholarworks.sjsu.edu/etd_theses/43

This Thesis is brought to you for free and open access by the Master's Theses and Graduate Research at SJSU ScholarWorks. It has been accepted for inclusion in Master's Theses by an authorized administrator of SJSU ScholarWorks. For more information, please contact scholarworks@sjsu.edu. 


\section{INFORMATION TO USERS}

The most advanced technology has been used to photograph and reproduce this manuscript from the microfilm master. UMI films the text directly from the original or copy submitted. Thus, some thesis and dissertation copies are in typewriter face, while others may be from any type of computer printer.

The quality of this reproduction is dependent upon the quality of the copy submitted. Broken or indistinct print, colored or poor quality illustrations and photographs, print bleedthrough, substandard margins, and improper alignment can adversely affect reproduction.

In the unlikely event that the author did not send UMI a complete manuscript and there are missing pages, these will be noted. Also, if unauthorized copyright material had to be removed, a note will indicate the deletion.

Oversize materials (e.g., maps, drawings, charts) are reproduced by sectioning the original, beginning at the upper left-hand corner and continuing from left to right in equal sections with small overlaps. Each original is also photographed in one exposure and is included in reduced form at the back of the book.

Photographs included in the original manuscript have been reproduced xerographically in this copy. Higher quality 6" $\times$ " 9 " black and white photographic prints are available for any photographs or illustrations appearing in this copy for an additional charge. Contact UMI directly to order.

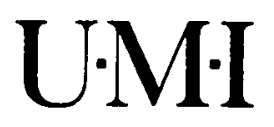

University Microfilms International

A Bell \& Howell Information Company

300 North Zeeb Road. Ann Arbor. MI 48106-1346 USA

$313 / 761-4700 \quad 800 / 521-0600$ 

Order Number 1342705

Parental care and diet of California gull (Larus californicus) chicks at Alviso, California

Dierks, Ann Jennifer, M.S.

San Jose State University, 1990

Copyright (C1991 by Dierks, Ann Jennifer. All rights reserved.

$\mathrm{U} \cdot \mathrm{M} \cdot \mathrm{I}$

300 N. Zeeb Rd.

Ann Arbor, MI 48106 

.... 
PARENTAL CARE AND DIET OF CALIFORNIA GULL (LARUS CALIFORNICUS) CHICKS AT ALVISO, CALIFORNIA

\author{
A Thesis \\ Presented to \\ The Faculty of Moss Landing Marine Labs \\ San Jose State University
}

In Partial Fulfillment

of the Requirements for the Degree

Master of Science

By

Ann Jennifer Dierks

December 1990 


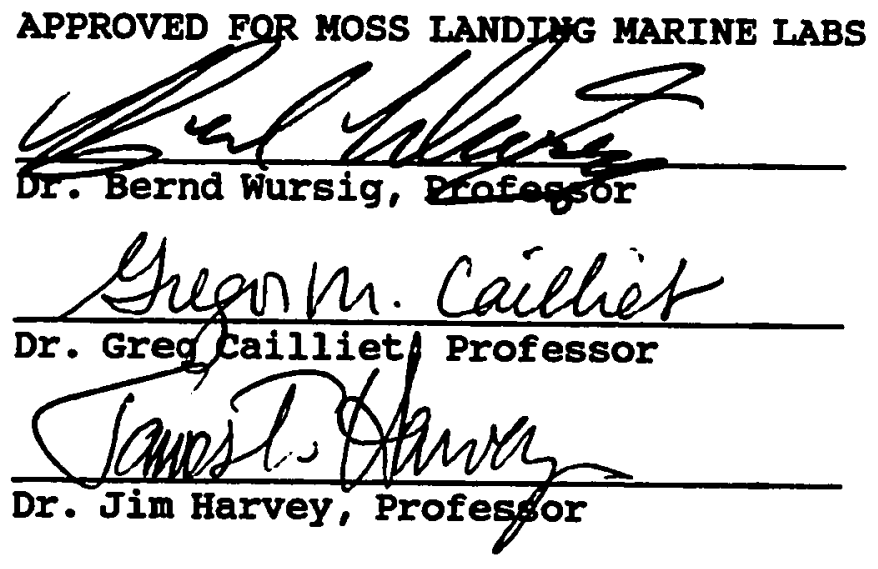

APPROVED FOR THE UNIVERSITY

terexe H. ytangore 


\author{
ABSTRACT \\ PARENTAL CARE AND DIET OF CALIFORNIA GULL \\ (LARUS CALIFORNICUS) CHICKS AT ALVISO, CALIFORNIA \\ by Ann Jennifer Dierks
}

From May to July 1987 and 1988, I examined the diet of chicks and aspects of parental care at a colony of California Gulls nesting on levees in a south San Francisco Bay salt pond, near Alviso, California. Overall chick diet by volume, as determined by regurgitated samples, was $40 \%$ garbage, $15 \%$ midges, $15 \%$ brine shrimp, $13 \%$ fishes, and $10 \%$ brine flies. Young chicks ( $\leq 10$ days) were fed more brine flies than older chicks. Similarity between morning and evening diets was only $50 \%$, with garbage, fishes, and polychaetes found more commonly in the morning and brine shrimp and insects in the evening. Parental attendance was equal to or greater than that of conspecifics at other colonies. Males were present significantly more than females ( 65 vs $48 \%$ of the time). Attendance in June was significantly greater than in July ( 1.3 vs 1.0 parents/nest). Foraging trips averaged 53 minutes. 
TABLE OF CONPBITS

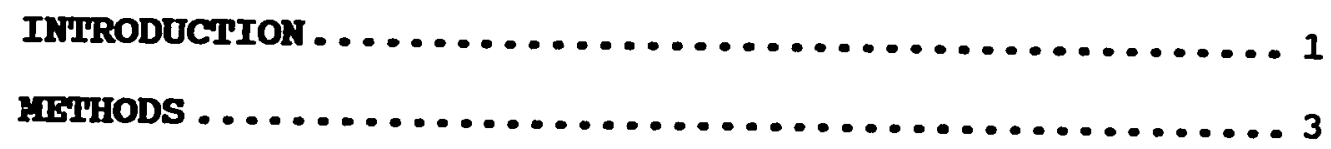

site description

Determination of diet

Description of behavior

RESULTS . . . . . . . . . . . . . . . . . . . . . . . . 11

Diet

Behavior

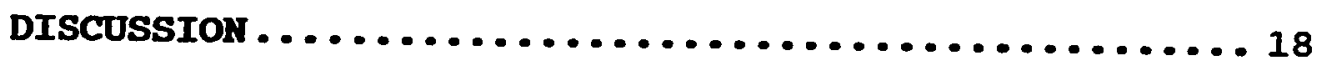

Diet

Behavior

ACKNONLEDGETEWTS . . . . . . . . . . . . . . . . . . . . . 40

LITERATURE CITED . . . . . . . . . . . . . . . . . . . . . . 41

Tables ..................................46

Figures ................................ 54 


\section{LIST OF TABLES}

TABLE 1. Comparison of food items produced when the stomach contents of individual chicks were sampled by both spontaneous and tubed regurgitations.

TABLE 2. Number/Volume ratios for commonly encountered prey .

TABLE 3. Comparisons of the diets of young ( $\leq 10$ days) and old (>10 days) chicks, based on regurgitated samples, as measured by a) $\%$ Volume and b) $\%$ Index of Relative Importance (IRI).

TABLE 4. Comparisons of the diets of chicks before and after June 14, based on regurgitated samples, as measured by a) $\%$ Volume and b) $\%$ Index of Relative Importance (IRI).

TABLE 5. Comparisons of the diets of chicks in morning and evening, based on regurgitated samples, as measured by a) $q$ Volume and b) $q$ Index of Relative Importance (IRI).

TABLE 6. Duration of foraging trips of nesting adults. TABLE 7. Composition of regurgitated samples from chicks for the four years diet has been examined at the Alviso colony. Data for 1983 and 1984 are from Jones (1986).

TABLE 8. Prey items found in regurgitated samples from chicks in 1987 and 1988 at the Alviso colony. 


\section{IIST OF FIGURES}

FIGURE 1. Study site.

FIGURE 2. Duration of absences and foraging trips of nesting adults.

FIGURE 3. Composition of regurgitated samples from chicks in 1987 and 1988 as measured by $\&$ Volume, $q$ Number, and $\%$ Frequency of Occurrence.

FIGURE 4. Composition of regurgitated samples from young ( $\leq 10$ days) and old (>10 days) chicks in 1987 as measured by $\&$ Volume, $q$ Number, and $\&$ Frequency of Occurrence.

FIGURE 5. Composition of regurgitated samples from young ( $\leq 10$ days) and old (>10 days) chicks in 1988 as measured by $\&$ Volume, $q$ Number, and $z$ Frequency of Occurrence.

FIGURE 6. Composition of regurgitated samples from chicks early and late in the prefledging period (before and after June 14) in 1987 as measured by $\%$ Volume, $z$ Number, and $z$ Frequency of Occurrence.

FIGURE 7. Composition of regurgitated samples from chicks early and late in the prefledging period (before and after June 14) in 1988 as measured by $\%$ Volume, $\%$ Number, and $\&$ Frequency of Occurrence. 
FIGURE 8. Composition of morning and evening regurgitated samples from chicks, for 1987 and 1988 combined, as measured by $\%$ volume, $q$ Number, and $\%$ Frequency of occurrence.

FIGURE 9. a) Mean percentage of time neither, one, or both parents were present at the nest for total observations ( $n=257$ nest-hrs), b) mean percent of time nesting adults were present at the nest in June and July ( $n=257$ nest-hrs), and $c$ ) mean percent of time males and females were present at the nest for total observations ( $n=163$ nesthrs).

FIGURE 10. Mean percentage of time neither, one, or both parents were present at the nest for $3-\mathrm{hr}$ intervals during the day in June and July $(n=257$ nest-hrs). 


\section{INTRODUCTION}

California Gulls (Larus californicus) are among several species of Larus gulls which have increased in population in the twentieth century (Conover 1983). Since the 1930's, both the breeding population and the number of colonies have increased. California Gulls nest at freshwater and saline lakes in the interior of the western U.S. and Canada. Roughly $33 \%$ of the U.S. population nests at Great Salt Lake, Utah or Mono Lake, California. The colony of California Gulls discovered near Alviso, California in 1980 represents a southwestern extension of the gull's breeding range, and is the first coastal colony documented (Jones 1986). The Alviso colony grew from approximately a dozen nests in 1980 to 2049 nests in 1988 (Jones 1986; Peg Woodin, San Francisco Bay Bird Observatory, pers. comm.).

Phenology at the Alviso colony is similar to that of inland colonies at similar latitudes. At Alviso, gulls begin courtship in early spring and most pairs lay 3 eggs in late April to mid May (Jones 1986). Eggs hatch after 25 days of incubation. Both parents share in guarding and feeding chicks. Chicks are fed by regurgitation, and remain at the colony until they can fly, at about 40 days of age. At Alviso, some fledged chicks (capable of flight) return to the colony to be fed until they are at least 65 days old. 
Diet, related behaviors, and food availability can influence reproductive success and limit the size of breeding populations in colonially nesting birds, including gulls (Ashmole 1963, Hunt 1972, Hunt and Hunt 1976, Murphy et al. 1984). The diet of gull chicks during the prefledging period has been investigated, and variations in diet such as those due to seasonal or diurnal fluctuations of prey species (Murphy et al. 1984, Vermeer 1970, Shuford 1985) or chick age (Kirkham and Morris 1979) have been documented. The amount of time parents spend foraging, and conversely, the amount of time they spend at the nest have also been studied. Parental attendance at the nest can be affected by the abundance or proximity of food (Hunt 1972, Pierotti 1981, Winkler 1983), and can affect chick survival (Burger 1982, Harris 1964).

Jones (1986) examined chick diet at Alviso in 1983 and 1984 as part of a broader study of reproductive biology at the colony. He found that the average bolus contained $40 \%$ garbage and $60 \%$ natural prey. Based on chick diet, parents were foraging in fresh and salt water, at salt evaporation ponds, beaches, levees, meadows, agricultural fields, and garbage dumps. He attributed the success of the Alviso colony in part to the seemingly abundant and predictable food supply. However, all samples were collected at night, and he published no information on changes in diet with chick age or season. 
To more fully understand diet and related behavior of California Gulls breeding at Alviso, and the suitability of the food supply relative to other breeding sites, I have: 1) documented the diets of gull chicks during two breeding seasons, 2) compared the diets of young and old chicks, 3) compared chick diets early and late in the prefledging period, 4) compared morning and evening chick diets, and 5) documented nest attendance and foraging trip length of adults. These variables were compared to those of other colonies.

METHODS

\section{Site Description}

This study was conducted at a colony site near coyote Creek at the southern tip of south San Francisco Bay, California (Fig. 1). Gulls nested on two insular levees in a Leslie salt Company salt evaporation pond, and on a nearby non-insular levee that served as a roadway. The insular levees were separated from the roadway levee by a channel approximately $20 \mathrm{~m}$ wide and $2 \mathrm{~m}$ deep. The levees, created during construction of the salt ponds, were approximately $10 \mathrm{~m}$ wide and $2 \mathrm{~m}$ high, with sparse vegetation. For a more detailed description of the colony site see Jones (1986). Determination of diet

Two methods were used to investigate diets of chicks at the Alviso colony. In 1987 and 1988, I collected regurgitated 
samples from chicks. In 1988, I made behavioral observations at the colony.

Sixteen trips were made to the Alviso colony to collect regurgitated samples between 17 May and 3 July 1987, and 14 trips between 28 May and 28 June 1988. Six evening trips were made in conjunction with San Francisco Bay Bird Observatory's banding program; on these trips samples were collected from chicks handled for banding. On other trips, chicks were selected for sampling based on age (an effort was made to collect samples from chicks of all ages present) and ease of capture (more mobile chicks were less likely to be caught). Up to 19 samples were collected per trip. Samples were placed in an ice chest with blue ice until they could be frozen. Based on the ease with which most food items were later recognized, further digestion of samples after collection was not a problem. For each sample collected, band number (if the chick was banded, 1987 only), wing chord (unflattened length from wrist to tip), time, and location within the colony were recorded.

At the Alviso colony, wing length was significantly correlated with age, the relationship being $y=-25.5+7.9 x$, $\left(r^{2}=0.90, p=0.001, N=164\right)$, where $y=$ wing chord in millimeters and $\mathrm{x}=$ age in days (Jones 1986). The division between 'young' and 'old' chicks for this study was set at $50 \mathrm{~mm}$ ( 10 days old). 
Two methods of collecting samples from chicks were compared. 'Spontaneous' samples were collected both years by holding a chick head-down over a container and waiting for the chick to regurgitate. In 1987 only, 'tubed' samples were collected by tubing 20 to $50 \mathrm{ml}$ of warm water into the chick's proventriculus before inverting the chick over the container (Duffy and Jackson 1986). Tubing was discontinued after 1987 for three reasons. First, in 1987 the diets of chicks based on spontaneous and tubed samples were significantly similar (see Results). In addition, 26 chicks were encouraged to spontaneously regurgitate, and then were tubed to see if additional stomach contents were produced. of the chicks which produced a sample, more than half did so without being tubed (see Results, Table 1). Finally, I felt that tubing put additional stress on chicks.

For each sample, I recorded the volume and number for each food category. Samples were thawed in random order and examined under a dissecting microscope. Because most detritus entered samples when a bolus fell on the ground during sample collection, detritus was eliminated before making measurements. Food volume was determined by water displacement in a 10,25 , or $100 \mathrm{ml}$ graduated cylinder. Brine shrimp and other small prey were pressed gently with a fork to remove excess water before measuring volume. Prey items were counted, or the number present was later calculated as 
described below. Garbage or items too digested to categorize were not enumerated. Unidentified prey were preserved in ethanol or formalin for further examination. Items found in very few samples and items too digested to be identified were placed in the miscellaneous category.

Because midges (Chironomus sp.), brine flies (Ephydra cinerea), and brine shrimp (Artemia salina) were frequently encountered and time-consuming to count, ratios were generated to allow estimation of the number of prey present in a sample based on volume (Table 2 ). For each of these prey, number and volume were determined for a portion of four 1987 samples. The mean number/volume ratio for each prey was used to calculate the approximate number of prey in these and other samples. When only one or a few prey occurred in a sample and the volume was too small to measure easily by displacement $(<0.1 \mathrm{ml})$ the ratio was used to calculate approximate volume.

For each food category, volume was converted to percentage by volume (i.e. food category volume/total sample volume), and the number of individuals for each category to percentage by number. Samples less than $1 \mathrm{ml}$ in volume, mostly obtained by tubing essentially 'empty' chicks, were judged to be poor indicators of the chick's most recent meal and were eliminated. 
Samples were pooled to determine the composition of diets, by percent volume and by percent Index of Relative Importance (IRI) (Pinkas et al. 1971).

$I R I=(\%$ volume $+q$ number $)(\%$ frequency of occurrence $)$

For 1987 and 1988 , diets were determined for:

1. total samples

2. samples from young ( $\leq 10$ days) and old ( $>10$ days) chicks

3. samples collected before and after June 14

4. morning and evening samples

5. spontaneous and tubed samples (1987 only)

The percent volume of each food category was averaged for all samples to determine overall percent volume. Each sample was thus assigned equal weight, regardless of size. Percent number, like volume, is the mean for all samples. No number was assigned to garbage, and samples containing only garbage were eliminated from percent number calculations. Frequency of occurrence is the percentage of samples in which a food category occurred. Food categories were scored as present even if only trace amounts were found. IRI's for food categories were converted to percent IRI, i.e. (food category IRI/total IRI for all food categories)(100). Adequacy of sample size for detection of food categories was tested by plotting cumulative number of species encountered against sample size for randomly chosen 1987 samples.

Percent similarity between diet pairs was calculated as: 


$$
\text { PS }=\sum_{n=1}^{i} \min p_{i}
$$

where $p_{i}$ is the percentage of the diet represented by each of n food categories (Sanders 1960). Diet pairs were tested for similarity with Spearman rank correlation (Siegel 1956). Rank correlation was used because of the very large sample sizes required for parametric tests (Duffy and Jackson 1986); for rank correlation, diets determined by 30 or more samples have a small probability of sampling error. The food categories used for calculating percent similarity, and for correlation testing, are the ones shown in Figure 3. Two significant digits were used when ranking categories for correlation testing.

Because the miscellaneous categories in two diets may represent different food items and not be comparable, the miscellaneous category was eliminated before making diet comparisons, and percentages for remaining food categories were multiplied by a factor so they again totaled $100 \%$. In this study miscellaneous prey were less than $2 \%$ of the diet by volume each year. One sample containing only a miscellaneous item was eliminated before diet comparisons were made.

In the Results and Discussion sections, percentages of food categories refer to percent volume in regurgitated 
samples, unless stated otherwise. Volume or mass are preferred methods of measuring items in stomach samples when food items vary greatly in size (Duffy and Jackson 1986) as was the case in this study. In my opinion volume was the single most meaningful measure of a food category's contribution to diet. Numerical abundance and frequency of occurrence tended to overestimate the importance of small prey, especially brine flies and brine shrimp, as samples often contained one or two brine flies or brine shrimp along with other foods which made up the bulk of the sample. Any numerical value assigned to garbage, the largest component of the diet by volume, would have been arbitrary. Most researchers at California Gull colonies have presented volume of food categories, and often frequency of occurrence as well (Shuford et al. 1984, 1985, Shuford 1985, 1986, Strauss 1987, Dierks 1988, 1990, Jones 1986, Vermeer 1970) making volume a better measure than IRI for comparisons among colonies. Description of behavior

Between 4 June and 26 July 1988, 313 nest-hours of behavioral data were collected at 14 nests. Four to seven nests were watched per session. The 12 sessions were 4 to 6 hours in duration. Sessions started as early as 5:45 am and ended as late as 8:50 pm. Six sessions were conducted between 4 and 17 June, and six between 16 and 26 July. 
I recorded starting and ending times, nest contents, weather conditions, arrivals and departures of adults and chicks, feedings, identity of parent feeding, and identity of food item (when possible). All study nests were within $10 \mathrm{~m}$ of the van I used as a blind, and were easily visible through binoculars. When possible the sex of adults at study nests was determined by size (Fox et al. 1981, Pierotti 1981). Members of a pair usually could be distinguished, even if the sex of each member was unknown. Nine adults had been banded. Chicks were aged by hatch date or plumage characteristics (Smith and Diem 1972).

The percentage of time parents were present at the nest was summarized for total observation time, for males and females, for June and July, and for intervals throughout the day. For calculating attendance, arrival and departure times were rounded off to the closest 5-minute mark, eliminating very short absences or presences. Two nests that were apparently tended by only one parent during part of the period of chick care were included for attendance calculations only for the period when both parents were tending; attendance at single-parent nests was summarized separately. Attendance for males and females, and for June and July, were compared with chi-square analysis (Zar 1984).

Mean duration of absences from the territory, and of foraging trips, were calculated. Those trips for which 
parents offered food to their chicks within 10 minutes of returning to the territory were considered known foraging trips. Trips <10 minutes and trips for which the adult was absent when the observation session began or ended were excluded. After determining that the distributions of foraging trip duration were roughly normal (Fig. 2), foraging trips for male and female, morning and afternoon, and June and July were compared with a two-sample t test ( $\operatorname{Zar} 1984$ ). The mean length of foraging trips immediately preceding the feeding of different food categories also were compared. As with parental attendance, single-parent nests were analyzed separately. Trips that began in the morning were considered morning trips even if they extended past noon.

For each nest under observation each day, food categories were scored as either present or absent. Diets, by frequency of occurrence, were compiled for total nest-days, and for June, July, morning (a few of which extended past noon), and afternoon nest-days. Nest-days which included only the unknown category were not included for summary purposes. Food offered to chicks at study nests was classified as fish, garbage, gull chick, small prey, or unknown.

RESULTS

Diets

In 1987 and 1988, garbage ranked first among food categories in regurgitated samples collected from chicks and 
was roughly $40 \%$ of the diets by volume, with natural prey making up the other $60 \%$ (Fig. 3). Ranks of food categories were almost identical for the two years, and were significantly correlated when compared by percent volume ( $r_{S}=$ $0.991, p<0.01)$ and by percent IRI $\left(r_{s}=0.882, p<0.05\right)$. Percent similarity was $85 \%$ by volume and $78 \%$ by IRI. Insects, as a group, ranked second to garbage. Midges (Chironomus sp., probably plumosus or stigmaterus), roughly $15 \%$ of the diets, and brine flies (Ephydra cinerea), roughly $10 \%$ of the diets, were the most commonly encountered insects. Brine shrimp (Artemia salina) and fishes (most commonly the longjaw mudsucker, Gillichthys mirabilis) were roughly $15 \%$ and $13 \%$ of the diets, respectively. Polychaete worms (Nereidae and Capitellidae) and insects (other than midges and brine flies) were a smaller percentage of the diets and were found in 1987 only. In 1987, plastic, glass, or metal occurred in 42 of 185 regurgitated samples.

overall, most differences between the diets of young ( $\leq 10$ days) and old (>10 days) chicks were not consistent when both years were considered. In 1987, regurgitated samples from young chicks contained more brine flies, fish, and polychaetes than samples from old chicks, whereas samples from old chicks contained more garbage, brine shrimp, and midges (Fig. 4). In 1988, diets of young and old chicks were 
similar except that samples from young chicks had more brine flies, whereas those from old chicks had more fish (Fig. 5). The average age of chicks sampled differed by only three days for the two years. In 1987, chicks averaged 14.0 days (mean wing chord $=84.9 \mathrm{~mm}, \mathrm{SD}=63.4, \mathrm{n}=133$ ). In 1988, chicks averaged 16.6 days (mean wing chord $=105.7 \mathrm{~mm}, \mathrm{SD}=$ $56.6, \mathrm{n}=145$ ).

Percent similarity values and rank correlation confirmed that the diets of young and old chicks were more similar in 1988 than 1987 (Table 3). The diets of young chicks were not significantly similar year to year. The diets of old chicks were significantly similar year to year $\left(r_{s}=0.982, p<\right.$ $0.01)$, probably because the sample sizes for old chicks were large and total diets for the two years were correlated. Despite the fact that gulls at the Alviso colony nest fairly synchronously (over $50 \%$ of nests initiated within the first 10 days of the egg-laying period [Jones 1986]) some samples were collected from young chicks ( $\leq 10$ days) after mid June and from old chicks (>10 days) before mid June. However, a large overlap exists between late season/old chick samples for both years. In 1987, $61 \%$ of early samples and $11 \%$ of late samples were from young chicks $(n=59)$. In 1988, sample size for young chicks was small $(n=29)$ and $23 \%$ of early samples and $16 \%$ of late samples were from young chicks. 
Most differences between diets early (before June 14) and late (after June 14) were small or not consistent for the two years studied (Fig. 6 and 7). In 1987, early samples contained more brine flies and polychaetes, whereas late samples contained more garbage and brine shrimp. In 1988, early samples had more brine shrimp, whereas late samples had more fish. The percentage of midges in the diet went from roughly $10 \%$ before mid June to $20 \%$ after mid June, both years. In 1988, early and late diets were correlated $\left(r_{S}=\right.$ $0.830,0.05>p>0.01$, Table 4).

Morning samples for 1987 and 1988 were significantly correlated $\left(r_{s}=0.741, p<0.05\right)$, as were evening samples for the two years $\left(r_{s}=0.937, p<0.01\right.$; Table 5). There were year to year differences, however. In 1987, morning samples were $19 \%$ polychaetes and $11 \%$ brine flies; in 1988 these categories were $0 \%$ and $3 \%$, respectively. In 1988, the percentage of garbage (62\%) in morning samples was much higher than in 1987 (35\%). There were no notable differences between years for evening samples. Within years, morning and evening samples were relatively dissimilar. Because of the similarity between years, all morning samples and all evening samples were pooled to compare morning and evening diets.

Dietary overlap between pooled morning and evening samples was only $50 \%$ by volume, with garbage accounting for $35 \%$ of that overlap. By IRI, dietary overlap was $34 \%$. 
Garbage, fishes, and polychaetes were more abundant in morning samples, whereas midges, brine shrimp, and brine flies were more abundant in evening samples (Fig. 8).

In 1987, diets of tubed chicks and of those which were not were correlated when ranked by percent volume $\left(r_{s}=0.746\right.$, p < 0.05), but not when ranked by percent IRI. Percent similarity was $86 \%$ by volume and $83 \%$ by IRI. of 26 chicks that were inverted, tubed, and inverted again, 23\% did not produce a sample at all, 39\% produced a sample without being tubed and were subsequently empty after tubing, $15 \%$ did not produce a sample until they were tubed, $15 \%$ produced a sample and when tubed produced more of the same food items, and $8 \%$ produced a sample and upon being tubed produced additional food items (Table 1). Sample size was too small to determine whether particular food items were more likely than others to be spontaneously regurgitated.

When cumulative number of food categories was plotted against sample size to determine adequacy of sample size, no new categories were added after 6, 7, 15, 15, or 16 of 135 samples, in five trials with randomly chosen samples. Behavior

Overall, both parents were present on their territory $27 \%$ of the time, one parent $62 \%$ of the time, and $11 \%$ of the time nests were unattended ( $n=257$ nest-hours; Fig. 9). The number of parents present on their territory was greater in 
June than July $\left(\chi^{2}=13.226, p<0.001\right)$, with attendance per parent decreasing from $66 \%$ to 51\%. By July, chicks had fledged and parents often spent more time at the nest than their chicks. Males were present $65 \%$ of the time and females $48 \%$, a significant difference $\left(\chi^{2}=9.406,0.005>p>0.001\right.$, $n=163$ nest-hours).

The most obvious difference in attendance patterns for June and July was that parents rarely left nests unattended in June, whereas in July nests were left unattended about $20 \%$ of the time (Fig. 10). In June, 1 parent tended to be away while the other remained at the nest in early morning and late afternoon. From 8:30 am until 5:30 pm it was somewhat more likely for both parents to be present. In July, attendance was highest in the evening. In my opinion, sample sizes for some 3-hour intervals during the day were too small to allow statistical testing of differences between intervals.

Attendance at 2 single-parent nests also decreased as chicks aged. Chicks less than about 18 days old were not left unattended for more than a few minutes at a time. Parents (one male, one of unknown sex) were observed stealing food from neighbors, a common practice among the gulls. Once single parents started making longer trips, the nest was left unattended about $33 \%$ of the time ( $n=23.1$ nest-hours). 
Overall, both absences and known foraging trips averaged 53 minutes in duration $(n=120$ and 57, respectively; Table 6). Male and female foraging trips were of similar duration. Foraging trips were somewhat longer in July, and in the afternoon, but differences were small. Parents who fed garbage to their chicks upon arriving at the nest were gone an average 46 minutes ( $n=24$ ), whereas those returning with small prey were gone 69 minutes $(n=15)$, a statistically significant difference $(t=2.421, p<0.05)$. In 4 trials with randomly chosen data points, the cumulative mean for length of absence stayed within $10 \%$ of the true mean after 8 , 35, 35, or 50 data points, respectively. Means derived from small sample sizes should be interpreted with caution.

Overall frequency of occurrence of food categories, for 47 nest-days of observation in 1988, were garbage 748 , small prey 38\%, fish 13\%, and gull chicks 9\%. There were no conspicuous differences in foods offered in the morning and the evening, or early and late in the season, and considering the small sample size, differences would be meaningless. Individual parents fed foods from more than one category to chicks, and did not appear to specialize in one type of food. Three dead gull chicks were offered as food during observations.

of 28 nesting birds at study nests, 7 were aged either by plumage (for birds $\leq 3$ years old) or bands (year-specific 
color bands applied when they were chicks). Two were 3-yearolds, three were 4-year-olds, and two were 5-year-olds. Reproductive success at study nests averaged one chick fledged/nest. Of 6 nests watched in both June and July, 3 fledged 1 chick, 1 fledged 2 chicks, and 2 nests had 1 chick still unfledged at the end of the study.

In 1987,133 of the 185 chicks from which regurgitated samples were collected had bands. Of these, only four were captured, and produced a sample, on two occasions. This indicates the assumption that each sample represents an independent data point is warranted.

DISCUSSION

Diet

The foods taken at Alviso (garbage, brine flies and other insects, fishes, brine shrimp, rodents, annelids, and vegetation) are similar to those documented at other California Gull colonies. Garbage, earthworms, brine flies, and brine shrimp were the major foods of chicks at the Great Salt Lake colony in 1982 (winkler 1983). During 10 years of sampling at Mono Lake, California, major items fed to chicks were brine shrimp, brine flies and other insects, other invertebrates, fishes, rodents, and garbage (Winkler 1983, Shuford et al. 1984, 1985, Shuford 1985, 1986, strauss 1987, Dierks 1988, 1990). At Miquelon and Beaverhill Lakes, Alberta, California Gull chicks were fed arthropods (mostly 
insects), amphibians, birds, rodents, and garbage. In northern Alberta, freshwater fishes can dominate the diet of adults (Vermeer 1970). Gulls typically take a wide variety of foods (Burger 1988), and diet of the chicks at the Alviso colony conforms to this generalization.

Although chick diets at the Alviso colony in 1987 and 1988 were correlated, year to year variations did exist. Year to year differences were more pronounced when the findings of Jones (1986), who examined diet at the Alviso colony in 1983 and 1984, were considered (Table 7). Garbage and insects have been dominant foods in every year studied. Fishes were less than $1 \%$ of the diet in 1983, whereas in 1984 they were more than 20\%. In 1983 and 1984 only, rodents were a sizeable portion of the diet, whereas in 1987 and 1988 only, brine shrimp were a sizeable portion of the diet. Polychaetes were a sizsable portion of the diet in 1987; no polychaetes were found in any other year.

Small differences in percentages of food categories presented in this study are probably meaningless. A very large sample size is needed to accurately determine the proportion of a diet represented by a food category (Duffy and Jackson 1986). For example, 400 samples are needed to determine the proportion of a prey making up $50 \%$ of the diet with a 958 chance of being within 58 of the true value. In addition, a regurgitated sample does not necessarily 
accurately reflect what a chick was fed, due to factors such as partial retention of stomach contents and differential digestion rates of foods.

Though differences between the diets of young and old chicks were found at Alviso both years, they were pronounced in 1987 only. Sample size for young chicks in 1988 was small $(n=29)$. Comparisons of diets using rank correlation require sample sizes of roughly 30 or greater (Duffy and Jackson 1986). Therefore, my representation of the diet of young chicks in 1988 may not be accurate enough for this comparison.

For both years, young chicks were fed more brine flies than old chicks, whereas for other food categories differences were small, inconsistent, or contradictory. Young chicks were fed more brine flies than early chicks as a whole, by $4 \%$ in 1987 and $7 \%$ in 1988. Further evidence that adults selectively feed brine flies to young chicks comes from Paul Jones (unpublished data). For the year 1983, he compared samples from early and late in the season. From May 25 to June 12, samples were primarily brine flies ( $62 \%$ by volume, $n=25$ ), whereas from June 13 to July 9 , garbage predominated ( $58 \%, n=33$ ). Jones also found that the mean age of chicks producing samples containing at least $90 \%$ brine flies was 7.1 days (std. dev. $=5.2, n=12$ ), whereas that of 
chicks producing samples containing at least $90 \%$ garbage was 13.9 days (std. dev. $=6.6, \mathrm{n}=17$ ).

Kirkham and Morris (1979) suggested that Ring-billed Gulls fed insects to young ( $<5$ days) chicks because insects are a good source of protein and are small enough for young chicks to swallow. This argument would also apply in Alviso where young chicks were fed more brine flies. Because the ageing technique was unreliable for chicks less than 10 days old (because few points were obtained at the lower end of the regression line), 10 days was chosen as the division between young and old chicks for this study. Had 5 days been chosen, greater differences between young and old might have been found. However, even the youngest chicks sampled (wing length $40 \mathrm{~mm}$ or less, $\mathrm{n}=55$ ) ate all food types, including fish and garbage.

Diurnal differences in diet are not unique to the Alviso colony. At Alviso, garbage, fishes, and polychaetes were more abundant in morning samples, whereas midges, brine shrimp, and brine flies were more abundant in evening samples. Eight years of study at Mono Lake, California, indicated a pattern in which morning samples contained more brine shrimp and evening samples contained more larger food items such as garbage, fish, and rodents (Jehl and Mahoney 1983, shuford et al. 1985, Shuford 1985, 1986, Strauss 1987, Dierks 1988, 1990). Adults feeding chicks in the morning probably foraged 
at the lake, whereas those arriving in the evening foraged farther from the colony (Jehl and Mahoney 1983, Shuford 1985). Jehl and Mahoney suggested a sexual component to this difference as well, with females foraging at the lake and males traveling to more distant sources of food. Hunt and Hunt (1976) collected food samples from Western Gull chicks on Santa Barbara Island, California. Squid were present on each of the 4 mornings they sampled but none of the 3 afternoons. Possibly this reflects the availability of squid to foraging gulls.

The large volume of garbage (approximately $30 \%$ to $50 \%$ of the diet) and the consistency with which it was fed to chicks (found in samples during each collecting trip I made to the colony) indicates its importance to the Alviso colony. The most common garbage items fed to chicks were a variety of meats. Starches such as potatoes and bread also were common. The prominence of garbage in the diet of the Alviso gulls is related to the colony's proximity to the dumpsites and cities of the south San Francisco Bay area. Several dumpsites operate within $15 \mathrm{~km}$ of the colony. Garbage is a highly concentrated, predictable source of food, though its consumption can present some drawbacks. Availability of human refuse is one of several factors responsible for recent increases in the populations of several gull species, including California Gulls (Conover 
1983). Sibley and McCleery (1983) stated that Herring Gulls, deprived of garbage dumps, could not breed at the colony site they studied. Hunt (1972) showed a relationship between chick survival and distance from several Herring Gull colonies to sources of edible refuse. The extent to which California Gulls feed garbage to their young varies among colonies. Garbage is a major food at the Great salt Lake colony where the wastes of Salt Lake City are within range; garbage is less important at Mono Lake which is not near any large urban area (Winkler 1983). Because garbage is exploited at Great Salt Lake, although natural foods are present in abundance, Winkler suggested that garbage is more desirable or can be obtained more efficiently than foods such as brine flies or brine shrimp. Hunt (1972) provided nutritional information on the foods of young Herring Gulls at his study site. His 'average mix' of garbage had more calories and protein than invertebrate prey but less than saltwater fishes. However, there are problems associated with eating refuse, such as botulism poisoning (Sutcliffe 1986). Pierotti (1983) found that individual Herring Gulls specializing on garbage had lower reproductive success than those specializing on other foods.

Fishes are an important food for gulls. Recent increase in the population of Ring-billed Gulls in the Great Lakes area was due, in part, to the introduction of alewives (Alosa 
pseudoharengus; Ludwig 1974). California Gulls breeding in northern Alberta feed extensively on fishes (Vermeer 1970). At Alviso, fishes were taken each year, but their percentage in the diet of chicks ranged from 0.28 to $21.3 \%$. The longjaw mudsucker was the most common fish prey, found in 15 of 27 samples containing fish. Other fishes fed to chicks include northern anchovy (Engraulis mordax), topsmelt (Atherinops affinis), staghorn sculpin (Leptocottus armatus), plainfin midshipman (Porichthys notatus), and surfperch (Embiotocidae) (Table 8). These species occur in the less saline salt ponds and in the bay itself. Freshwater fishes were not found in 1987 and 1988, but were found in an earlier study (Jones 1986).

Fishes were found almost exclusively in morning samples. Fishes were absent on only 3 of 15 morning sampling trips, whereas only 4 evening samples contained fish. Most fish species consumed by the gulls, including the longjaw mudsucker, live in several of the Leslie salt ponds of lowest salinity (Lonzarich 1989). Possible causes of their presence in morning samples are the diurnal fluctuation of dissolved oxygen in the salt ponds, wind patterns, or tidal height. Photosynthesis in the salt ponds leads to a high dissolved oxygen level during the day, but the level falls at night due to respiration (Carpelan 1957, Lonzarich 1989). Mudsuckers are able to absorb oxygen from air in a highly vascularized 
bucco-pharyngeal chamber. Under low oxygen conditions they periodically come to the surface to gulp a mouthful of air (Todd 1968). Alternatively they may swim into very shallow water at the edges of the ponds at night (Jerry Smith, San Jose State University, pers. comm.). Either way, under low oxygen conditions mudsuckers are more likely to be at the surface of the ponds (Lonzarich 1989) where they become more accessible to foraging gulls. Other fish species in the salt ponds also may be more accessible when oxygen levels are low. Whereas mornings are usually calm at the colony, the wind picks up in the afternoon, probably reducing the ability of gulls to see fish below the water's surface. During months when chicks were present, the tide was usually lower in early morning than in late afternoon. However, this factor seems to have been of little importance, at least for the years 1987 and 1988. Although longjaw mudsuckers typically live in intertidal regions of sloughs, estuaries, and mudflats (Barlow 1961), they are rare in San Francisco Bay (Aplin 1967, Jerry Smith, pers. comm.). Gulls probably take longjaw mudsuckers from the nontidal salt ponds, where they are abundant. Also, fishes were present in morning samples during and following high tide. For two morning trips when the tide was not below +2 feet from dawn to the start of sampling, fishes occurred in 4 out of 10 and in 5 out of 9 samples. 
The role of brine shrimp in the diet of California Gulls varies among colonies. Brine shrimp flourish in salt ponds surrounding the Alviso colony, and occur naturally in Great Salt and Mono Lakes. Brine shrimp were over $50 \%$ of the diet of chicks at the Mono Lake colony in 5 of 10 years of study (winkler 1983, Shuford et al. 1984, 1985, Shuford 1985, 1986, Strauss 1987, Dierks 1988, 1990). At Great Salt Lake, brine shrimp made up about $10 \%$ of the diet of chicks in 1982 (Winkler 1983), and were essentially absent during an earlier study of adult food habits covering 4 years between 1939 and 1946 (Greenhalgh 1952). Several authors have expressed the opinion that brine shrimp are less 'preferred' than larger foods (Shuford 1985, Winkler 1983), or than brine flies, which are more nutritious than brine shrimp (Dave Herbst, Sierra Nevada Aquatic Research Lab, per. comm.). However, at Mono Lake, brine shrimp were a large percentage of chick diet in two years when brine shrimp populations were high (Winkler 1983, Dierks 1990). Brine shrimp often are abundant in the environment, but must be picked out of the water one or a few at a time by swimming gulls. It takes 1965 brine shrimp to make a typical $15 \mathrm{ml}$ bolus (Table 2). Jones (1986) suggested Alviso gulls did not feed on brine shrimp in 1983 and 1984 because of the abundance of other food in the area. For some reason, perhaps colony growth, the gulls had begun to exploit 
this resource by 1987, and brine shrimp were about $15 \%$ of the diet of chicks in 1987 and 1988 .

California Gulls are known for foraging extensively on insects. In Salt Lake City, the Mormons erected a monument to honor California Gulls for helping save the early settlers' crops from destruction by crickets. Indeed, in a Great salt Lake study covering 4 years between 1939 and 1946, grasshoppers (Locustidae) made up over $50 \%$ of the diet of adult Great Salt Lake gulls (Greenhalgh 1952). At Mono Lake, brine flies were the major insect prey, and in some years cicadas (Cicadidae) were taken commonly (Winkler 1983, Shuford et al. 1984, 1985, Shuford 1985, 1986, Strauss 1987, Dierks 1988, 1990). At Miquelon and Beaverhill Lakes, insects, mostly ground beetles (Carabidae) and damsel fly (Coenagrionidae) naiads, made up roughly $40 \%$ of the diet in June 1965 (Vermeer 1970). At Alviso, gulls consumed large numbers of brine flies and midges.

California Gulls nesting at hypersaline lakes often feed on brine flies (Ephydra sp.). Brine flies are also found at the salt ponds of south San Francisco Bay. At Alviso, brine flies ranged from essentially $0 \%$ to $38 \%$ of the diet of chicks over 4 years of study. Whether the large variation among years in the importance of brine flies as a food for the gulls is due to variation in availability or to some other factor is unknown. At the Mono Lake colony, annual variation 
in brine fly consumption has also been great; brine flies ranged from about $5 \%$ to $47 \%$ of chick diet during 10 years of study (Winkler 1983, Shuford et al. 1984, 1985, Shuford 1985, 1986, Strauss 1987, Dierks 1988, 1990). At Great Salt Lake brine flies made up about $15 \%$ of the diet of chicks in one recent year (Winkler 1983) but less than $1 \%$ of adult diet in an earlier study which included samples from 4 different years (Greenhalgh 1952). Brine flies are a good source of nutrition (Herbst et al. 1983) and occur in dense "patches" in the environment. Like brine shrimp, they must be captured one or a few at time.

Midges were about $15 \%$ of chick diet at Alviso in 1987 and 1988, and also were found in 1983 and 1984 (Jones 1986). Midges are preyed upon by California Gulls at other colonies as well (Greenhalgh 1952, Vermeer 1970). At Alviso, most midges were taken just as the pupae were molting into adults. Midge pupae are found in fresh to slightly brackish marshes, and are abundant in salt ponds and sewage percolation ponds (Wes Faffei, San Jose State University, pers. comm.). All these habitats occur near the Alviso colony. Midges float on the water's surface as the adults emerge from the puparium. In addition to being accessible and concentrated at this stage in their life history, the midges also are more easily digestible soon after molting (Wes Faffei, pers. comm.). Most midges were fed to gull chicks in the afternoon or evening. 
One factor that may make midges more accessible in the afternoon or evening is the afternoon winds, which concentrate floating prey on the downwind side of ponds. Diurnal patterns of emergence of adult from pupal midges also may be involved.

California Gulls at Alviso also took other insects typical of salt marshes, salt pond levees, and dry fields (Table 8 ). Long-horned (Tettigoniidae) and short-horned (Acrididae) grasshoppers were found in 13 samples in 1987. Eleven of these were collected one evening and one more was from the next morning. Only one 1988 sample contained grasshoppers. Grasshoppers are common on trails and levees around the salt ponds.

The presence of polychaete worms in 1987 samples seemed to be related to tidal height. All samples containing nereid worms were collected in the morning, in May. Eleven of 12 were found when a negative tide had occurred between dawn and the start of sampling. Capitellids were found in morning samples from May, June, and July $(n=5)$, and when the tide had dropped to +1.5 or lower between dawn and the start of sampling. Perhaps Jones (1986) found no polychaetes in 1983 or 1984 because he sampled only at night. However, I did not find any in 1988 morning samples.

Plastic ingestion by seabirds has recently become a concern. In 1987, plastic, glass, or metal occurred in 42 of 
185 regurgitated samples (including samples <1 ml). Plastic often was found when tubed samples were collected from essentially 'empty' chicks. Under these circumstances the undigestible remains of previous meals, such as detritus and insect exoskeletons, were all that were produced. The amount of plastic found in most samples was small enough to be considered trivial, one or a few pieces $0.5 \mathrm{ml}$ in diameter. The manner in which adults ingest the plastic can only be guessed, but floating pieces of plastic may be intentionally ingested as gulls forage on small aquatic prey. Or perhaps plastic sticks to other foods at dumps and is incidentally ingested.

Some annual, seasonal, and diurnal variation in the diet of Alviso gulls depends on the availability of food items. Annual variation may explain the presence of polychaetes and rodents in certain years only. Seasonal changes in availability may cause variations such as the increase in midge consumption after mid June 1987 and 1988. Many diurnal differences in diet at the Alviso colony seem to be related to prey availability. Factors other than the ones mentioned may affect the availability of food to foraging gulls. In addition, individual gulls do not necessarily take foods in proportion to their availabilities, but may specialize in one or more available foods (McCleery and sibly 1986). An examination of food availability in the Alviso area would 
provide insight into additional factors affecting availability and might also reveal whether gulls have preferences for certain foods.

\section{Behavior}

The amount of time parents are present at the nest can affect the survival of their chicks. Insufficient parental care may cause predation of chicks in a number of bird species (Lack 1968, Harris 1969, Ashmole 1971, Hunt 1972). In gulls the loss of chicks to predatory gulls, of the same or another species, can be high (Burger 1982, Harris 1964). Weather also can cause mortality when parents are not present to shelter chicks (Harris and Plumb 1965, Hand et al. 1981). The degree of coordination between parents is as important as the actual amount of time they are present. Pugesek (1981) studied differences in rates of nest attendance, feeding, and territorial defense among young, middle-aged, and old pairs of California Gulls nesting in Wyoming. He found that old parents, who as a group coordinated their behavior so that one parent foraged while the other was at the nest, fledged more chicks. Though younger parents spent almost as much time at the nest, they were more apt to both be present or absent. Therefore, percentage of time a nest is unattended may be a more meaningful measure of parental care than the number of parents/nest averaged over time. Morris (1987) found that successful pairs of Herring Gulls coordinated their 
attendance so that young chicks were rarely left unattended, and that partners of successful pairs spent roughly equal amounts of time at the nest. Other researchers also have found that male and female gulls split attendance fairly equitably (Burger 1981, Butler and Janes-Butler 1983, Pierotti 1981).

The rate of parental attendance at the Alviso colony, an average of 1.2 parents/nest, is similar to or higher than that reported for other colonies. When converted to common units for comparison, the average rate of parental attendance over the prefledging period was 1.1 parents/nest at Great Salt Lake (Winkler 1983); roughly 0.75 at Mono Lake (Winkler 1983); 1.0 at Sprague Lake, Washington (Conover and Miller 1980); and 1.0 at a colony near Laramie, Wyoming (Pugesek 1981). However, due to differences in methods these figures are not directly comparable.

My results must be interpreted with caution because the nests observed may not be representative of the colony as a whole, and because the number of nests at which gulls were sexed with confidence was small (163 nest-hours of observations at 8 nests). My observations were of gulls nesting along a levee used as a road. This area of the colony might be considered suboptimal, being more accessible to mammalian predators, and more recently colonized, than the nearby insular levees. Reproductive success at the edge of a 
gull colony is often not as high as in the center, with younger, less successful pairs often nesting at the edge (Pugesek and Diem 1983). Whether the ages of adults at nests I watched ( 7 of 28 known to be $\leq 5$ years old) were representative of the colony is unknown, but many colorbanded 3 to 5 year old birds nested in all areas of the colony in 1988. Two study nests were initiated considerably later than the peak. Reproductive success of birds at study nests was roughly 1 chick fledged/nest, similar to that found for the colony in 1983 and 1984 (Jones 1986). Determining the number of chicks/nest in July was difficult because chicks were not marked and spent much of their time away from the territory.

At Alviso, males were present more than the females $(73 \%$ versus $56 \%$ of the time in June, and $56 \%$ versus $40 \%$ in July). In addition, of 2 nests where chicks essentially were raised by a single parent, one single parent was male and the other was of unknown sex. Pierotti (1981) found that male western Gulls on Southeast Farallon Island were present more than females in 1973, a poor food year, but not in 1974 when food was more abundant. He attributed the disproportionate presence of males to piracy. Pirates, gulls that steal food from other gulls, were male, and spent much more time at the nest than their mates. Piracy also was observed at Alviso, though not to the extent described by Pierotti. 
Parents typically reduce the amount of time they spend at the nest as chicks grow older. Older chicks are less susceptible to predation, requiring less protection by parents. Also, older chicks need more food, requiring parents to spend more time foraging. In early to mid June, when the chicks at my study nests were approximately 1 to 27 days old, parents were present at the rate of 1.3 parents/nest and chicks were rarely left unattended. This figure is slightly higher than that reported for chicks of similar age at Great Salt Lake (1.0 to 1.2) and much higher than at Mono Lake (0.6 to 1.1; Winkler 1983). By mid to late July, most chicks at my study nests were approximately 47 to 67 days old, though 3 were less than 32 days old at the start of my July observation period. Parental attendance by this time had dropped to 1.0 parents/nest with nests left unattended about $20 \%$ of the time. Comparable data were not available for Great Salt Lake or Mono Lake. Winkler (1983) ended his observations at these colonies at a chick age of 49 days. However, he found that attendance dropped off sharply with chick age at Mono Lake whereas at Great Salt Lake it remained fairly constant.

In July, the fledged chicks (capable of flight) I observed were present at the nest on and of during the day, but usually returned between 5:00 and 8:00 pm. Chicks are capable of sustained flight at about 40 days old. The chicks 
were often fed in the evening, though feedings occurred at other times as well. Parents spent more time at the nest than their fledged chicks. Postfledging care at Alviso closely parallels that described by Burger (1981) for a New Jersey colony of Herring Gulls. She found that chicks up to 80 days old returned to the colony to be fed. The age at which chicks stop returning to be fed at the Alviso colony is unknown. When my study ended, chicks up to 65 days old were still being fed at the colony. At inland colonies, when adults migrate to the coast they are separated from their chicks and parental care ends. This occurs when the chicks are about 45 to 60 days old at Mono and Great Salt Lakes (Winkler 1983). It would be interesting to compare the duration of parental care at Alviso to that of inland colonies.

At Alviso, the morning low in parental attendance may have been due to parents' foraging for their own or their chicks' first meal of the day, whereas the evening high in July may have been related to attendance patterns of fledged chicks, described above. Daily patterns of parents tending chicks vary among gull colonies. Conover and Miller (1980) found more adults present morning and evening and fewer at midday. At other colonies the number of adults present remained fairly constant during the day but increased in the evening (Galusha and Amlaner 1978, Butler and Janes-Butler 1983). Gulls that forage extensively on intertidal organisms 
can exhibit a pattern of attendance at the territory influenced by tidal height (Galusha and Amlaner 1978). At Alviso, polychaetes are the only prey I found that were clearly intertidal in origin (intertidal fishes also occur in salt ponds), and presumably tidal height had little effect on parental attendance.

Although parental attendance was lower at single-parent nests, single parents successfully fledged chicks. A single parent provided most of the care for chicks at 2 of the 6 nests observed in both June and July. At each nest, both parents cared for the chicks until the chicks were about 10 days old. For the remainder of my June observations, the next 10 to 15 days, only one parent was seen. The 'missing' parent from one nest reappeared during my July observations. The other missing parent, a female, was never seen again. Until the chicks were about 20 days old, the 2 single parents were only seen to leave the territory for a few minutes at a time, apparently to steal food from other gulls. Once parents started leaving for longer periods, attendance at the singleparent nests averaged about 0.66 parents/nest. Single-parent chicks suffered more attacks by adults. At each of these nests 1 chick had fledged and was still being fed in late July .

Average length of foraging trips at Alviso (53 minutes, $n=57$ ) was similar to that found by Hunt (1972) at a colony 
of Herring Gulls nesting $4 \mathrm{~km}$ from a dump that supplied much of its food ( 44 minutes). In contrast, on Santa Barbara Island, Western Gulls fed primarily on anchovies and squid, and foraged an average 2.13 hours (Hunt and Hunt 1976). My plots of cumulative mean versus sample size indicate that sample size for total foraging trips was sufficient. However, long foraging trips would be underrepresented by my sampling technique. Because observations were made during 4 to 6 hour stints, it was impossible to record both the departure and arrival for long trips. Thus, the average duration of foraging trips at Alviso may be greater than reported. Regardless of the uncertainty of mean foraging trip length, the numerous foraging trips under an hour in duration indicate that many gulls foraged near the colony.

Although sample size was small, gulls returning to the Alviso colony with small prey had been absent longer ( 69 minutes) than those returning with garbage (46 minutes; $n=$ 15 and 24, respectively). This may indicate that gulls travel farther to forage on small prey, or that small prey take longer to acquire. Both garbage dumps, and the habitats of the small prey found in regurgitated samples (brine shrimp, insects, polychaetes, and shrimp), occur near the colony.

Several authors have reported a relationship between parental attendance and food availability. Winkler (1983) reported parental attendance of California Gulls at Great 
Salt Lake was higher than at Mono Lake due to more abundant and closer sources of food and water at the Great salt Lake colony. Hunt (1972) studied parental attendance at Herring Gull colonies at varied distances from food sources and found attendance was lower at colonies farther from food. Pierotti (1981) found that attendance at a Western Gull colony was higher in a good food year than in a poor food year. Furness and Hislop (1981) assumed that all time parents were away from the nest was spent foraging, and used nest attendance of Great Skuas as an indication of food availability. In contrast, both Herring Gulls (Pierotti 1987) and California Gulls (Winkler 1983) have spent equal amounts of time at the nest during both a good and poor food year. Some authors have commented that parents may rest away from the colony (Conover and Miller 1980, Galusha and Amlaner 1978). Although I have no way to judge whether parent gulls at Alviso foraged the whole time they were away from the nest, one indication that they did not is that parents did not feed begging chicks upon every return.

In summary, several variables suggest that at Alviso food is not difficult for gulls to obtain. Parental attendance at Alviso was similar to or greater than at other colonies, and chicks under three weeks old were seldom left unattended. Single-parents successfully fledged chicks. Three-year-olds bred successfully at study nests, and a 2- 
year-old has been documented as breeding successfully at Alviso (Don Starks, San Francisco Bay Bird Observatory, pers. comm.). The mean duration of foraging trips of under an hour indicates that food is available near the colony. 


\section{ACKNOWLEDGEHEITS}

This study was made possible by the generosity of the many people who helped with fieldwork, identified prey, and shared their knowledge with me. Leslie Salt company granted access to the colony, and San Francisco Bay National Wildlife Refuge granted permits for my research there. San Francisco Bay Bird Observatory helped with logistics and loaned equipment, and many of the people who assisted with fieldwork were observatory members. I want especially to thank Dave Shuford who introduced me to California Gulls; Peg Woodin who provided me a home away from home; Paul Jones, who, though he probably didn't realize it, encouraged me at my lowest point, and Lyman Fancher and Bill Muench for their help and encouragement. And, I certainly could not have succeeded in this project without the help of my committee members Greg Cailliet and Jim Harvey, and my advisor Bernd Wursig. 


\section{LITERATURB CITED}

Ashmole, N. P. 1971. Sea bird ecology and the marine environment. In Avian Biology, vol.1, ed. D. S. Farner and J. R. King, 223-286. New York: Academic Press.

Ashmole, N. P. 1963. The regulation of numbers of tropical oceanic birds. Ibis 103b: 458-473.

Aplin, J.A. 1967. Biological survey of San Francisco Bay 1963-1966. State of California, The Resources Agency, Dept. of Fish and Game, Marine Resources Operations Ref. N. 67-4.

Barlow, G. W. 1961. Intra- and interspecific difference in rate of oxygen consumption in gobiid fishes of the genus Gillichthys. Biological Bulletin 121 (2): 209-229.

Burger, J. 1988. Foraging behavior in gulls: differences in method, prey, and habitat. Colonial waterbirds 11 (1): 9-23.

Burger, J. 1982. An overview of proximate factors affecting reproductive success in colonial birds: concluding remarks and summary of panel discussion. Colonial Waterbirds 5: 5865 .

Burger, J. 1981. On becoming independent in Herring Gulls: parent-young conflict. American Naturalist $117(4): 444-456$.

Butler, R. G. and S. Janes-Butler. 1983. Sexual differences in the behavior of adult Great Black-backed Gulls (Larus marinus) during the pre- and post-hatch periods. Auk 100:

Carpelan, L. H. 1957. Hydrobiology of the Alviso salt ponds. Ecology 38(3): 375-390.

Conover, M. R. 1983. Recent changes in Ring-billed and California Gull populations in the western United states. Wilson Bulletin 95(3): 362-383.

Conover, M. R. and D. E. Miller. 1980. Daily activity patterns of breeding Ring-billed and California Gulls. Journal of Field Ornithology $51(4): 329-339$. 
Dierks, A. J. 1990. Population size and reproductive success of California Gulls at Mono Lake, California in 1989, with emphasis on the Negit Islets. Point Reyes Bird observatory contribution No. 466 .

Dierks, A. J. 1988. Population size and reproductive success of California Gulls at Mono Lake, California in 1988, with emphasis on the Negit Islets. Point Reyes Bird observatory contribution No. 413.

Duffy, D C. and S. Jackson. 1986. Diet studies of seabirds: a review of methods. Colonial Waterbirds $9(1): 1-17$.

Fox, G. A., et al. 1981. Predicting the sex of Herring Gulls by using external measurements. Journal of Field Ornithology 52(1): 1-9.

Furness, R. W. and J. R. G. Hislop. 1981. Diets and feeding ecology of Great Skuas (Catharacta skua) during the breeding season in Shetland. Journal of Zoology (London) 195: 1-23.

Galusha, J. G., Jr. and C. J. Amlaner. Jr. 1978. The effects of diurnal and tidal periodicities in the numbers and activities of Herring Gulls (Larus argentatus) in a colony. Ibis 120: 322-328.

Greenhalgh, C. M. 1952. Food habits of the California Gull in Utah. Condor 54: 302-308.

Hand, J. L. et al. 1981. Thermal stress and predation: influences on the structure of a gull colony and possibly on breeding distributions. Condor 83(3): 193-203.

Harris, M. P. 1969. The biology of storm petrels in the Galapagos Islands. Proceedings of the California Academy of Sciences 37 (Series 4): 95-165.

Harris, M. P. 1964. Aspects of the breeding biology of the gulls (Larus argentatus), ( $L$. fuscus), and ( $L$. marinus). Ibis 106: 432-456.

Hunt, G. L. 1972. Influence of food distribution and human disturbance on the reproductive success of Herring Gulls. Ecology 53 (6): 1051-1061. 
Hunt, G. L. and M. W. Hunt. 1976. Exploitation of fluctuating food resources by Western Gulls. Auk 93: 301-307.

Jehl, J. R., Jr. and S. A. Mahoney. 1983. Possible sexual differences in foraging patterns in California Gulls and their implications for studies of feeding ecology. Colonial Waterbirds 6: 218-220.

Jones, P. A. 1986. Aspects of the reproductive biology of the California Gull in Alviso, California. M. A. thesis, San Francisco State University, California.

Kirkham, I. R. and R. D. Morris. 1979. Feeding ecology of Ring-billed Gull (Larus delawarensis) chicks. Canadian Journal of Zoology 57: 1086-1090.

Lack, D. L. 1968. Ecological adaptations for breeding in birds. London: Methuen.

Lonzarich, D. G. 1989. Temporal and spatial variations in salt pond environments and their implications for $f i s h$ and invertebrates. M. A. thesis, San Jose State University, California.

Ludwig, J. P. 1974. Recent changes in the Ring-billed Gull population and biology in the Laurentian Great Lakes. Auk $91(3)$ : 575-594.

McCleery, R. H. and R. M. Sibly. 1986. Feeding specialization and preference in Herring Gulls. Journal of Animal Ecology 55: 245-259.

Morris, R. D. 1987. Time-partitioning of clutch and brood care activities in Herring Gulls: a measure of parental quality? In Studies in Avian Biology, No. 10, ed. J. L. Hand et al., 68-74. Cooper Ornithological Society. Lawrence,
Kansas: Allen Press.

Murphy, E. C., et al. 1984. Dietary changes and poor reproductive performance in Glaucous-winged Gulls. Auk 101:
$532-541$. 
Pierotti, R. 1987. Behavioral consequences of habitat selection in the Herring Gull. In Studies in Avian Biology, No. 10, ed. J. I. Hand et al., 119-126. Cooper ornithological Society. Lawrence, Kansas: Allen Press.

Pierotti, R. 1983. Diet and reproductive output in seabirds. Bioscience $40(8)$ : 568-574..

Pierotti, R. 1981. Male and female parental roles in the Western Gull under different environmental conditions. Auk 98: 532-549.

Pinkas, I. et al. 1971. Food habits of albacore, bluefin tuna, and bonito in California waters. California Fish and Game, Fish Bulletin 152: 1-105.

Plumb, W. J. and M. P. Harris. 1965. Experiments on the ability of Herring Gulls (Larus argentatus) and Lesser Black-backed Gulls ( $L$. fuscus) to raise larger than normal broods Ibis 107: 256-257.

Pugesek, B. H. 1981. Increased reproductive effort with age in the California Gull (Larus californicus). Science 212: 822-823.

Pugesek, B. H. and K. L. Diem. 1983. A multivariate study of the relationship of parental age to reproductive success in California Gulls. Ecology 64(4): 829-839.

Sanders, H. L. 1960. Benthic studies in Buzzards Bay III. The structure of the soft-bottom community. Limnology \& Oceanography 5(2): 138-153.

Shuford, W. D. 1986. Population size and reproductive success of California Gulls at Mono Lake, California in 1986, with special reference to the Negit Islets. Point Reyes Bird Observatory contribution No. 347 .

Shuford, W. D. 1985. Reproductive success and ecology of California Gulls at Mono Lake, California in 1985, with special reference to the Negit Islets: an overview of three years of research. Point Reyes Bird observatory contribution No. 318 . 
Shuford, D. et al. 1985. Population size and breeding success of California Gulls at Mono Lake, California, in 1984. Point Reyes Bird Observatory contribution No. 294.

Shuford, D. et al. 1984. Population size and breeding success of California Gulls at Mono Lake, California, in 1983. Point Reyes Bird Observatory contribution No. 126.

Sibly, R. M. and R. H. Mccleery. 1983. Increase in weight of Herring Gulls while feeding. Journal of Animal Ecology 52: 35-50.

Siegel, S. 1056. Nonparametric Statistics for the Behavioral Sciences. New York: McGraw-Hill.

Smith, J. E. and Kenneth I. Diem. 1972. Growth and development of young California Gulls (Larus californicus). Condor $74(4): 462-470$.

Strauss, E. 1987. Population size and reproductive success of California Gulls at Mono Lake, California in 1987, with emphasis on the Negit Islets. Point Reyes Bird Observatory contribution No. 377 .

Sutcliffe, S. J. 1986. Changes in the gull populations of SW Wales. Bird Study 33: 91-97.

Todd, E. S. 1968. Terrestrial sojourns of the long-jaw mudsucker (Gillichthys mirabilis). Copeia 1968: 192-194.

Vermeer, K. 1970. Breeding biology of California and Ringbilled Gulls: a study of ecological adaptation to the inland habitat. Canadian Wildlife Service Report Series No. 12: 152 .

Winkler, D. W. 1983. Ecological and behavioral determinates of clutch size: the California Gull (Larus californicus) in the Great Basin. Ph D. diss., University of California, Berkeley.

Zar, J. H. 1984. Biostatistical Analysis. 2d ed. Englewood Cliffs, New Jersey: Prentice-Hall. 


$\begin{array}{lll}\text { Chick \# } & \begin{array}{l}\text { Items produced } \\ \text { spontaneously }\end{array} & \begin{array}{l}\text { Items produced } \\ \text { when tubed }\end{array} \\ 1 & \text { P, BF } & \text { BF, G, P } \\ 2 & \text { I, BF } & \text { I, BF } \\ 3 & \text { F, G, BF } & \text { BF, G } \\ 4 & \text { G, BS } & - \\ 5 & \text { G, I, BS } & - \\ 6 & \text { M, I } & \text { M, I } \\ 7 & \text { G, M, I } & - \\ 8 & - & \text { G, BS, BF } \\ 9 & \text { G, M, I } & - \\ 10 & \text { G, I } & - \\ 11 & \text { F, G } & - \\ 12 & \text { F } & - \\ 13 & - & \text { BS, BF, G, I } \\ 14 & \text { BS, G } & \text { BS, BF, G } \\ 15 & - & \text { BF } \\ 16 & - & \text { M, BF, I } \\ 17 & - & - \\ 18 & - & - \\ 19 & \text { BS } & - \\ 20 & - & - \\ 21 & - & - \\ 22 & - & - \\ 23 & \text { G, BF } & - \\ 24 & \text { G, BF, BS } & \text { BF, BS } \\ 25 & \text { M, BF } & - \\ 26 & - & -\end{array}$

TABLE 1. Comparison of food items produced when the stomach contents of individual chicks were sampled by both spontaneous and tubed regurgitations. After chicks were encouraged to spontaneously regurgitate, tubed samples were collected by tubing 20 to $50 \mathrm{ml}$ of warm water into the chick's proventriculus and inverting the chick over a container. Food items are listed in descending order by \% Volume. BF $=$ brine flies, $B S=$ brine shrimp, $F=$ fish, $G=$ gabage, $I=$ insects, $M=$ midges, $P=$ polychaetes. 


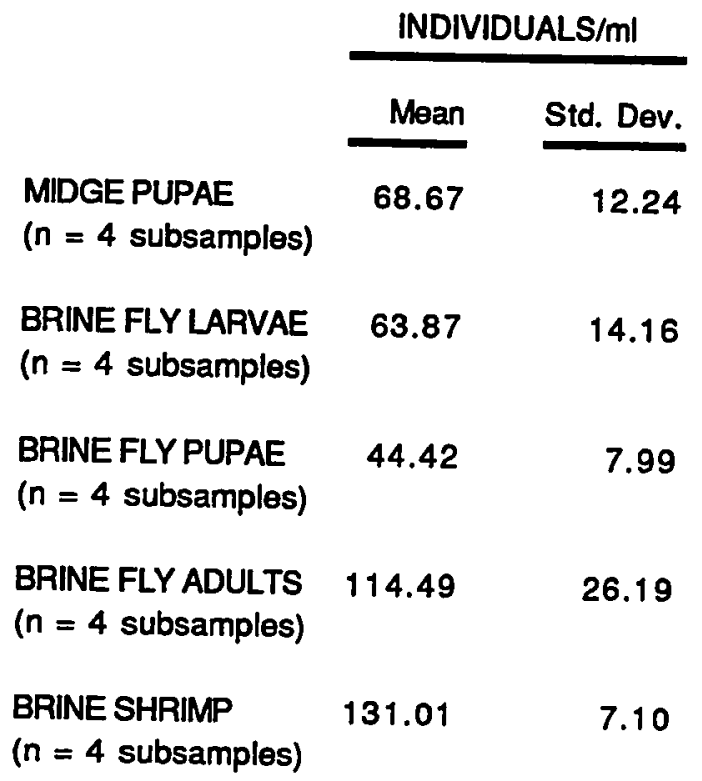

TABLE 2. NumberNolume ratios for commonly encountered prey. 


\begin{tabular}{|c|c|c|c|c|}
\hline a. \% VOLUME & Young 1987 & Old 1987 & Young 1988 & Old 1988 \\
\hline $\begin{array}{r}\text { Young } 1987 \\
n=59\end{array}$ & & $P S=63 \%$ & $P S=63 \%$ & \\
\hline $\begin{array}{r}\text { Old } 1987 \\
n=74\end{array}$ & $r_{8}=0.214$ & & & $P S=84 \%$ \\
\hline $\begin{array}{r}\text { Young } 1988 \\
n=29\end{array}$ & $r_{s}=0.527$ & & & $P S=87 \%$ \\
\hline $\begin{array}{c}\text { Old } 1988 \\
n=116\end{array}$ & & $r_{s}=0.882^{* \prime}$ & $r_{s}=0.750^{*}$ & \\
\hline
\end{tabular}

\begin{tabular}{|c|c|c|c|c|}
\hline b. $\%$ IRI & Young 1987 & Old 1987 & Young 1988 & Old 1988 \\
\hline $\begin{array}{r}\text { Young } 1987 \\
n=59\end{array}$ & & $P S=51 \%$ & $P S=57 \%$ & \\
\hline $\begin{array}{r}\text { Old } 1887 \\
n=74\end{array}$ & $r_{s}=-0.107$ & & & $P S=81 \%$ \\
\hline $\begin{array}{r}\text { Young } 1988 \\
n=29\end{array}$ & $r_{s}=0.468$ & & & $P S=83 \%$ \\
\hline $\begin{array}{l}\text { Old } 1988 \\
n=116\end{array}$ & & $r_{s}=0.847^{\circ}$ & $r_{s}=0.745^{\circ}$ & \\
\hline
\end{tabular}

TABLE 3. Comparisons of the diets of young ( $\$ 10$ days) and old (>10 days) chicks, based on regurgitated samples, as measured a) by $\%$ Volume and b) by $\%$ Index of Relative Importance (IRI). IRI = (\% Volume + \% Number) (\% Frequency of Occurrence) (Pinkas ot al. 1971).

Percent similarity (PS) $=\sum_{n=1}^{1}$ min $\mathrm{Pi}_{i}$ where $\mathrm{pi}_{\mathrm{i}}$ is the percentage of the diet represented by each of $n$ prey items (Sanders 1960). Spearman rank correlation (Siegel 1956) was used to test for
statistical similarity between diets. 


\begin{tabular}{|c|c|c|c|c|}
\hline a. \% VOLUME & Before $6 / 14 / 87$ & After $6 / 14 / 87$ & Before $6 / 14 / 88$ & After $6 / 14 / 88$ \\
\hline 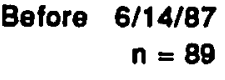 & & $P S=69 \%$ & $P S=72 \%$ & \\
\hline After $\begin{array}{r}6 / 14 / 87 \\
n=46\end{array}$ & $r_{s}=0.366$ & & & $P S=84 \%$ \\
\hline 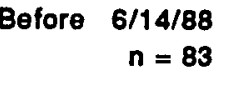 & $r_{s}=0.313$ & & & $P S=82 \%$ \\
\hline $\begin{array}{r}\text { After } \begin{array}{r}6 / 14 / 88 \\
n=63\end{array}\end{array}$ & & $r_{\delta}=0.777$ & $r_{s}=0.830^{\circ}$ & \\
\hline
\end{tabular}

\begin{tabular}{|c|c|c|c|c|c|}
\hline b. & $\%$ IRI & Before $6 / 14 / 87$ & After $6 / 14 / 87$ & Before $6 / 14 / 88$ & After $6 / 14 / 88$ \\
\hline Betore & $\begin{array}{r}6 / 14 / 87 \\
n=89\end{array}$ & & $P S=58 \%$ & $P S=65 \%$ & \\
\hline After & $\begin{array}{r}6 / 14 / 87 \\
n=46\end{array}$ & $r_{s}=0.393$ & & & $P S=75 \%$ \\
\hline Before & $\begin{array}{r}6 / 14 / 88 \\
n=83\end{array}$ & $r_{s}=0.634$ & & & PS $=72 \%$ \\
\hline After & $\begin{array}{r}6 / 14 / 88 \\
n=63\end{array}$ & & $r_{s}=0.634$ & $r_{s}=0.750$ & \\
\hline
\end{tabular}

TABLE 4. Comparisons of the diets of chicks before and after June 14, based on regurgitated samples, as measured a) by \% Volume and b) by \% Index of Relative Importance (IRI).

$I R I=$ (\% Volume + \% Number) (\% Frequency of Occurrence) (Pinkas et al. 1971).

Percent similarity (PS) $=\sum_{n=1}^{i} \min p_{i}$, where $p_{i}$ is the percentage of the diet represented by each of $n$ prey items (Sanders 1960). Spearman rank correlation (Siegel 1956) was used to test for statistical similarity between diets. 
a. \% VOLUME

\begin{tabular}{|c|c|c|c|}
\hline AM 1987 & PM 1987 & AM 1988 & PM 1988 \\
\hline$r_{S}=0.000$ & PS $=54 \%$ & $P S=73 \%$ & \\
\hline$r_{S}=0.741^{*}$ & & & $P S=92 \%$ \\
\hline & $r_{S}=0.937^{* *}$ & $r_{S}=0.524$ & $P S=45 \%$ \\
\hline & & & \\
\hline
\end{tabular}

b.

\begin{tabular}{|c|c|c|c|c|}
\hline$\% \mid \mathbf{R I}$ & AM 1987 & PM 1987 & AM 1988 & PM 1988 \\
\hline $\begin{array}{r}A M \begin{array}{r}1987 \\
n=57\end{array}\end{array}$ & & $P S=43 \%$ & $P S=64 \%$ & \\
\hline $\begin{array}{r}P M \begin{array}{r}1987 \\
n=78\end{array}\end{array}$ & $r_{s}=-0.545$ & & & PS $=90 \%$ \\
\hline $\begin{array}{r}A M \quad 1888 \\
n=60\end{array}$ & $r_{s}=0.711$ & & & $P S=28 \%$ \\
\hline $\begin{array}{r}P M \quad 1988 \\
n=86\end{array}$ & & $s=0.972^{* *}$ & $r_{s}=0.115$ & \\
\hline
\end{tabular}

TABLE 5. Comparisons of the diets of chicks in morning and evening, based on regurgitated samples, as measured a) by \% Volume and b) by \% Index of Relative Importance (iRi).

$\mid \mathrm{IAI}=$ (\% Volume $+\%$ Number)(\% Frequency of Occurrence) (Pinkas ot al. 1971).

i

Percent similarity $(P S)=\sum_{n=1} \min p_{i}$, where $p_{1}$ is the percentage of the diet represented by each of $n$ prey items (Sanders 1960). Spearman rank correlation (Siegel 1956) was used to test for
statistical similarity between diets. 


\section{LENGTH OF FORAGING TRIPS (min.)}

$\begin{array}{lll}\text { ALL TRIPS }(n=57) & \frac{\text { Mean }}{53} & \frac{\text { Std. Dev. }}{29} \\ \text { TRIPS BY MALES }(n=21) & 49 & 27 \\ \text { TRIPS BY FEMALES }(n=23) & 51 & 21 \\ \text { TRIPS IN JUNE }(n=50) & & \\ \text { TRIPS IN JULY }(n=7) & 51 & 28 \\ \text { AM TRIPS }(n=23) & 70 & 34 \\ \text { PM TRIPS }(n=34) & 48 & 34 \\ & 57 & 26 \\ \text { FOOD BROUGHT BACK: } & & \\ \text { Garbage }(n=24) & & \\ \text { Small prey (n=15) } & 46 * & 28 \\ & 69 & 30 \\ \text { * } 0.05>p>0.01 & & \end{array}$

TABLE 6. Duration of foraging trips of nesting adults. Trips $<10 \mathrm{~min}$. were excluded. Foraging trips were trips after which adults fed chicks within 10 min. of return.

Differences were tested with a t test (Zar 1984). 
Percent of Diet by Volume

\begin{tabular}{lcccr} 
Category & $\begin{array}{c}1983 \\
N=58\end{array}$ & $\begin{array}{c}1984 \\
N=48\end{array}$ & $\begin{array}{c}1987 \\
N=136\end{array}$ & $\begin{array}{r}1988 \\
=146\end{array}$ \\
\hline Garbage & 42 & 37.7 & 34 & 47 \\
Insects & 46 & 20.8 & 29 & 25 \\
Fishes & 0.2 & 21.3 & 13 & 13 \\
Brine Shrimp & & & 14 & 16 \\
Rodents & 5 & 6.1 & & \\
Polychaetes & & & 8 & \\
Vegetation & 6 & 4.4 & & \\
Miscellaneous & 9.7 & 2 & $<1$ \\
\hline
\end{tabular}

TABLE 7. Composition of regurgitated samples from chicks for the four years diet has been examined at the Alviso colony. Data for 1983 and 1984 are from Jones (1986). 


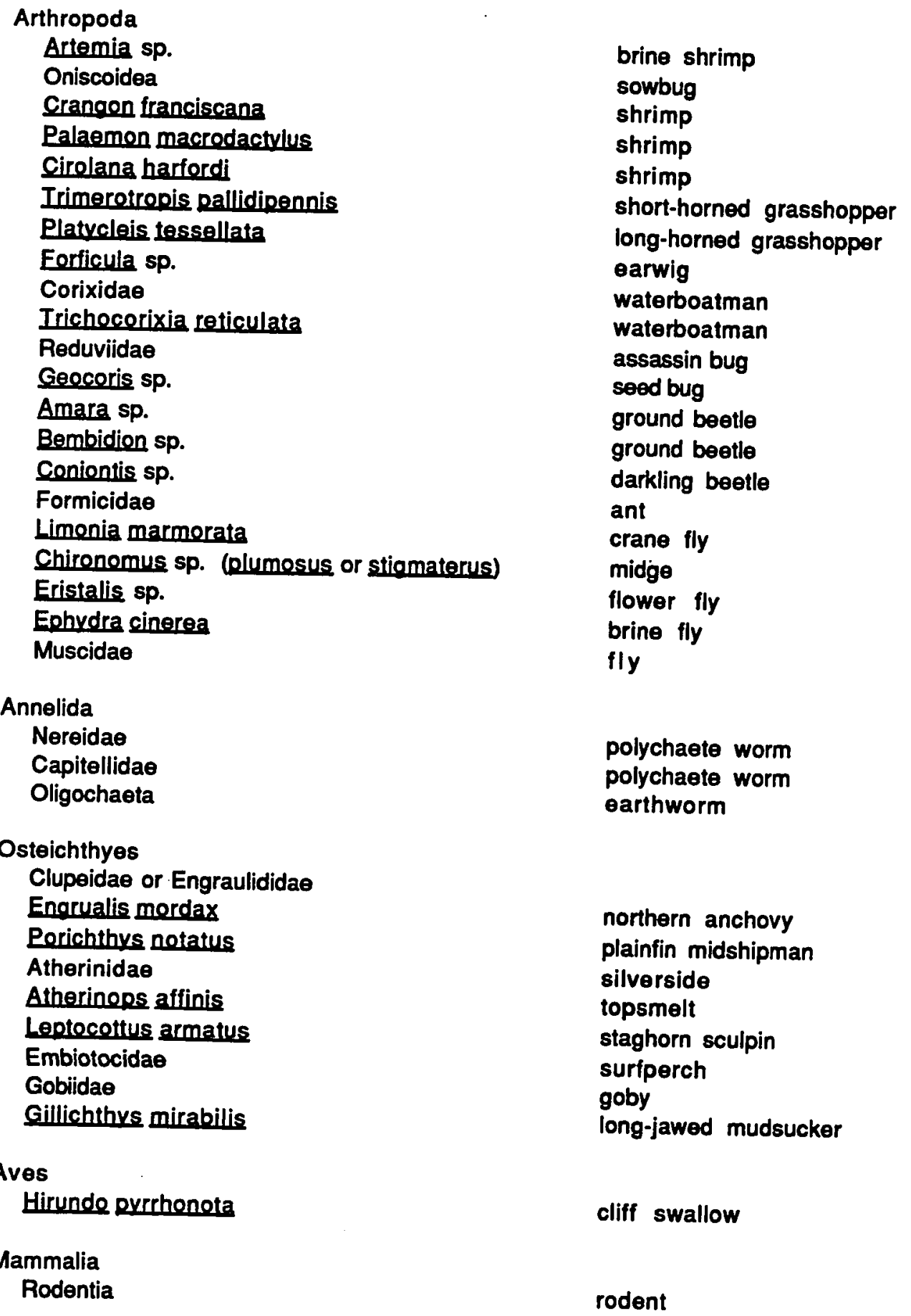

TABLE 8. Prey items found in regurgitated samples from chicks in 1987 and 1988 at the Alviso colony. 


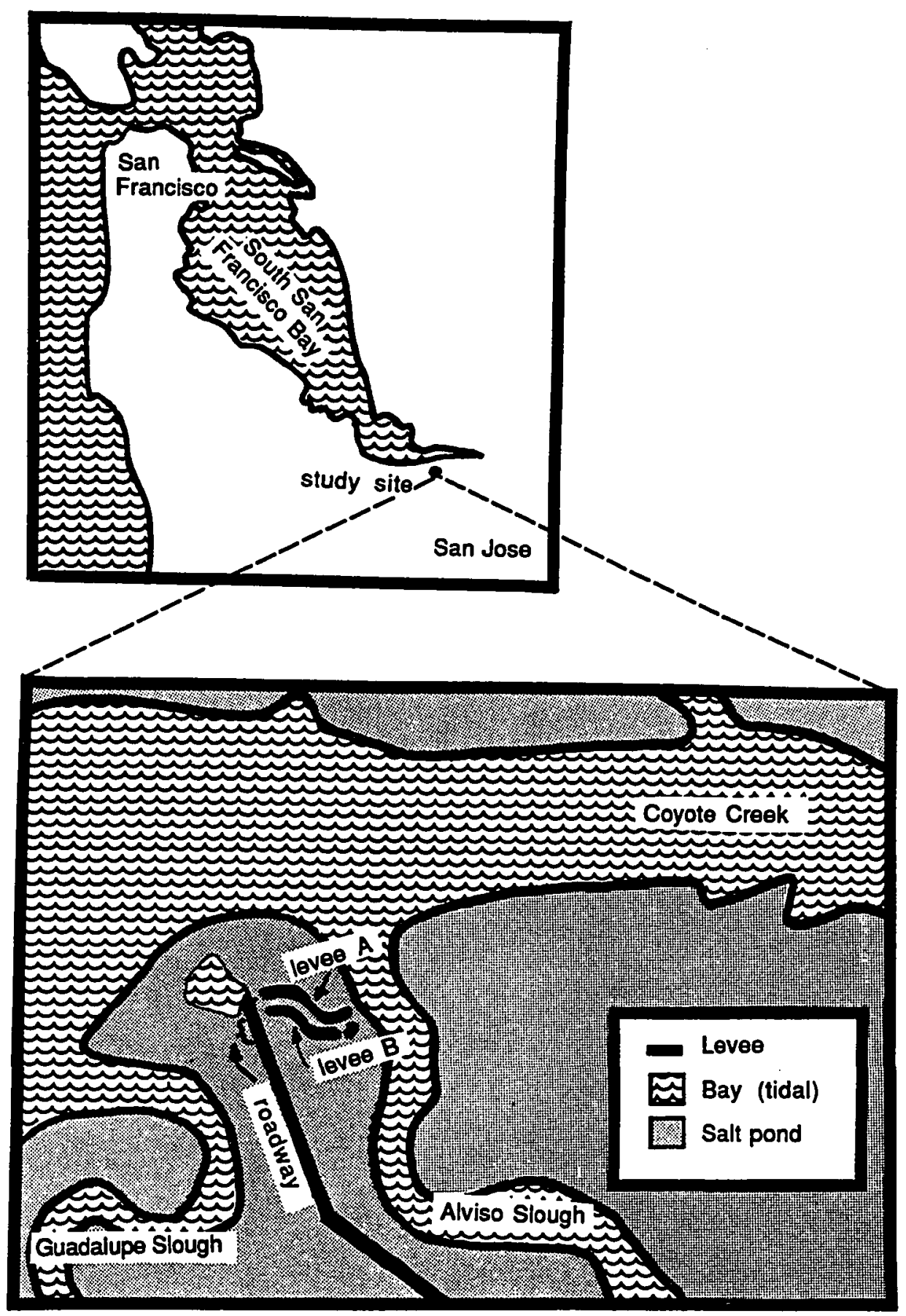

FIGURE 1. Study site. Gulls nested on levees A and B and along the roadway in the area indicated by the bracket. 


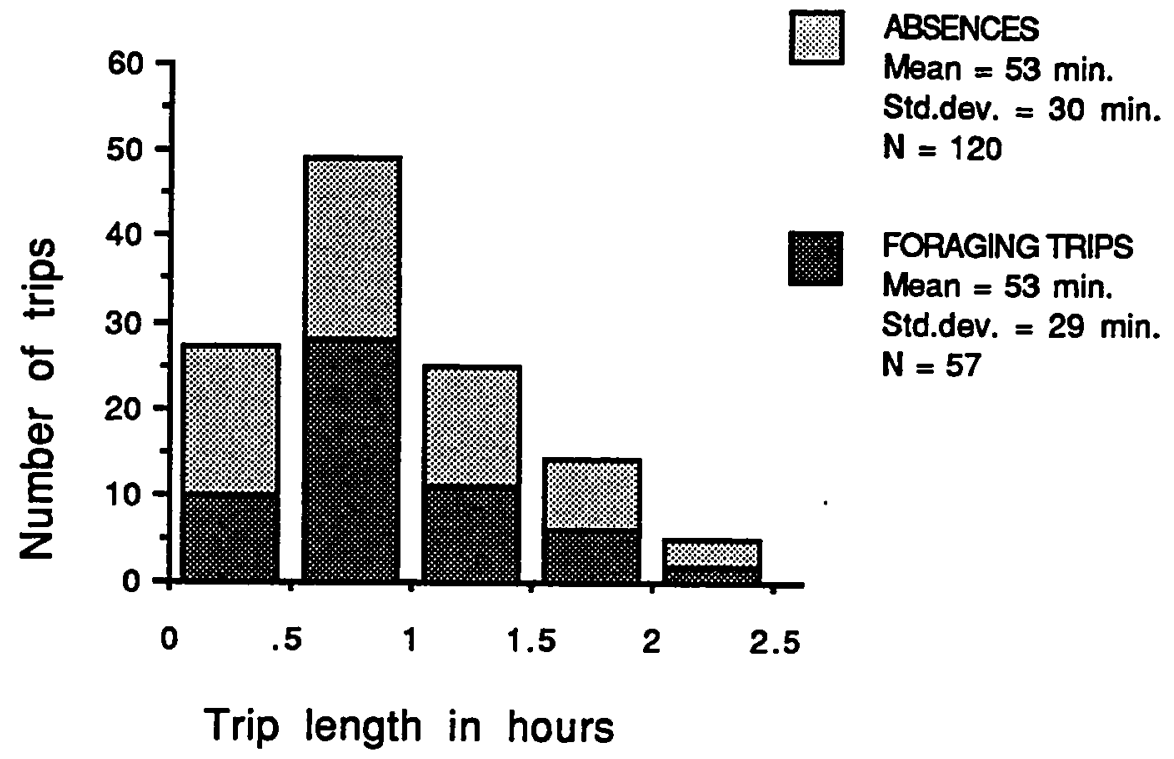

FIGURE 2. Duration of absences and foraging trips of nesting adults. Absences $<10 \mathrm{~min}$. were excluded. Foraging trips were trips after which adults fed chicks within $10 \mathrm{~min}$. of return. 

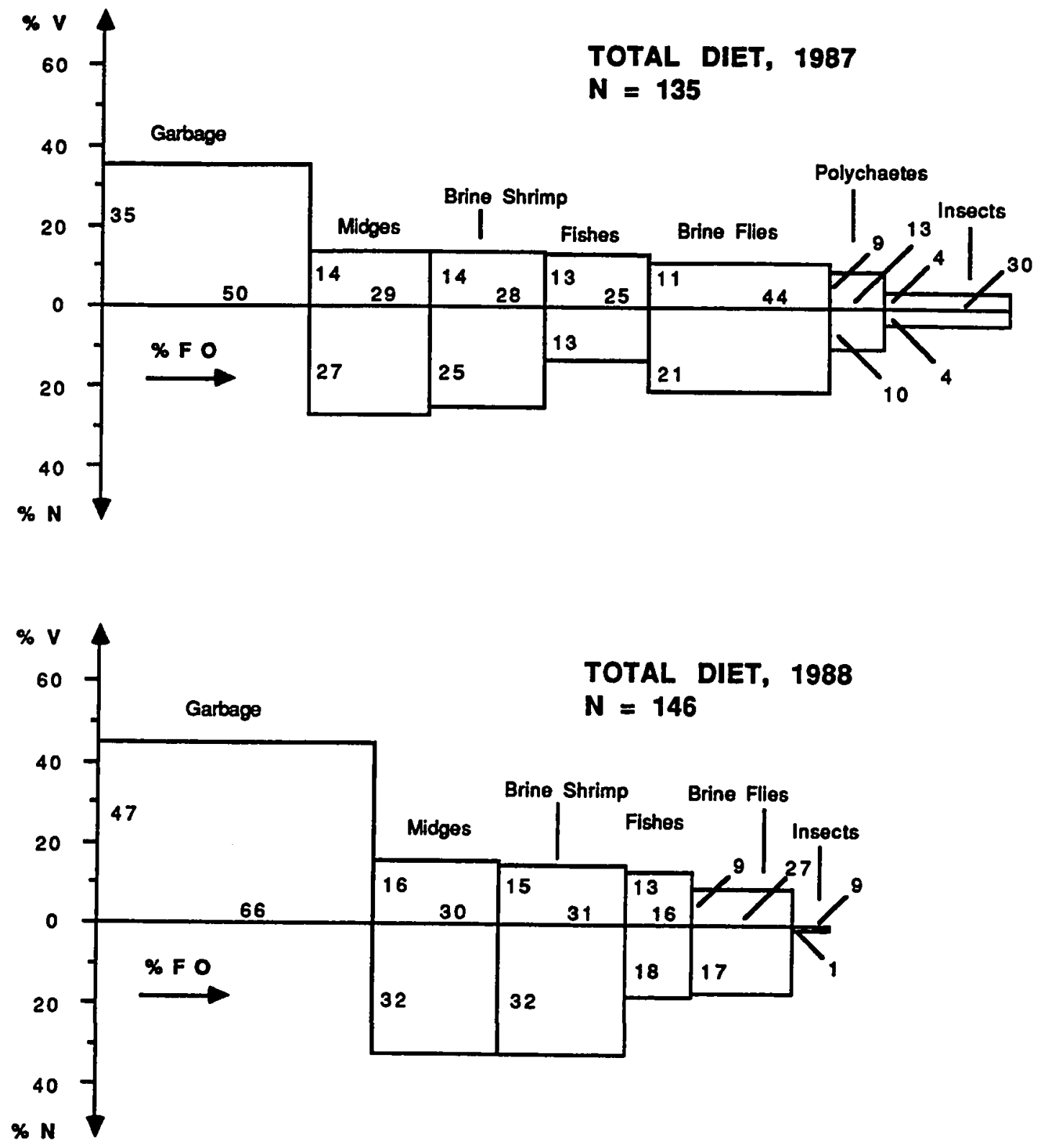

FIGURE 3. Composition of regurgitated samples from chicks in 1987 and 1988 as measured by \% Volume, \% Number and \% Frequency of Occurrence. No number was assigned to garbage during $\%$ Number calculations. 

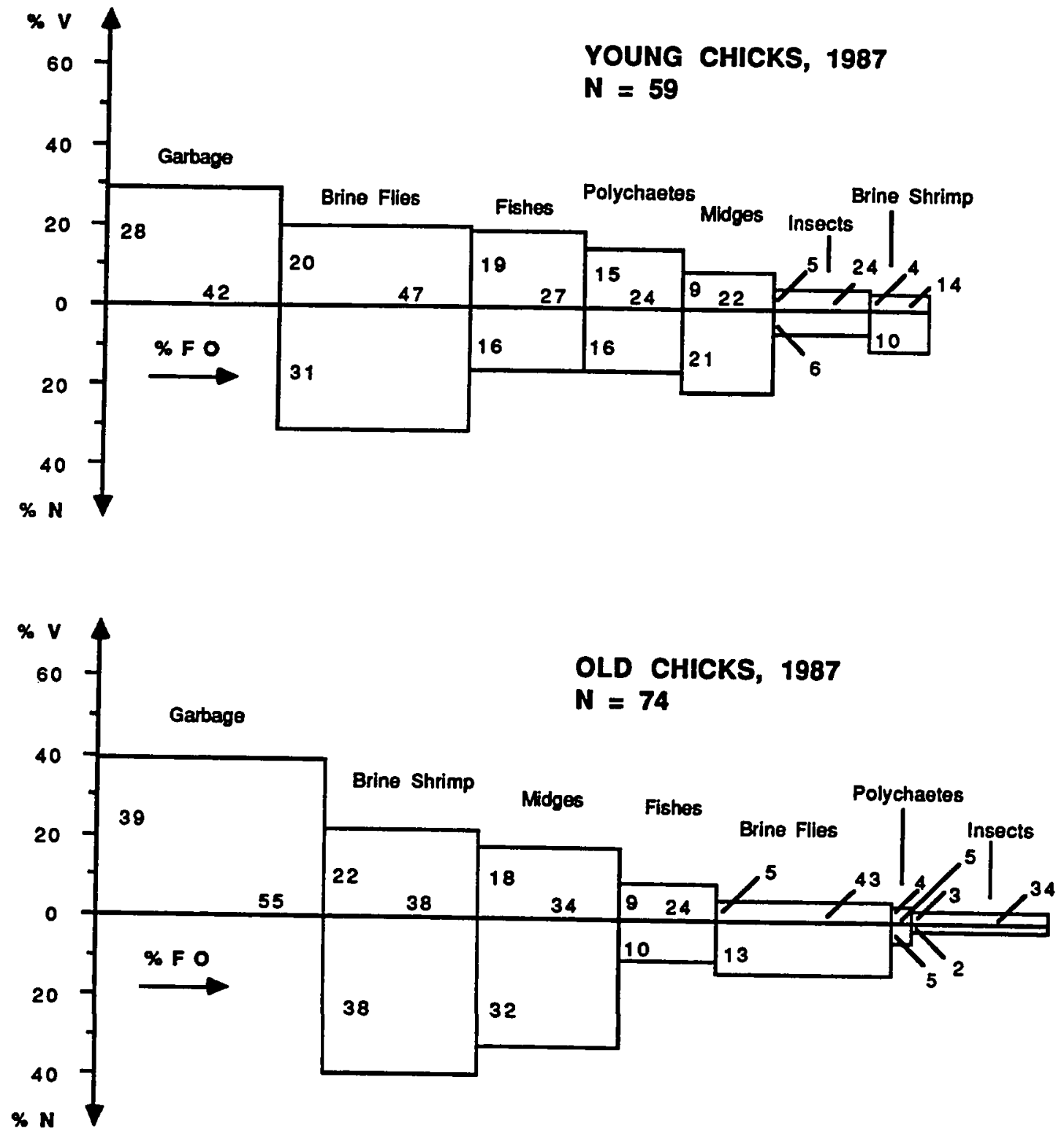

FIGURE 4. Composition of regurgitated samples from young ( $\$ 10$ days) and old (>10 days) chicks in 1987 as measured by \% Volume, \% Number and \% Frequency of Occurrence. No number was assigned to garbage during \% Number calculations. 

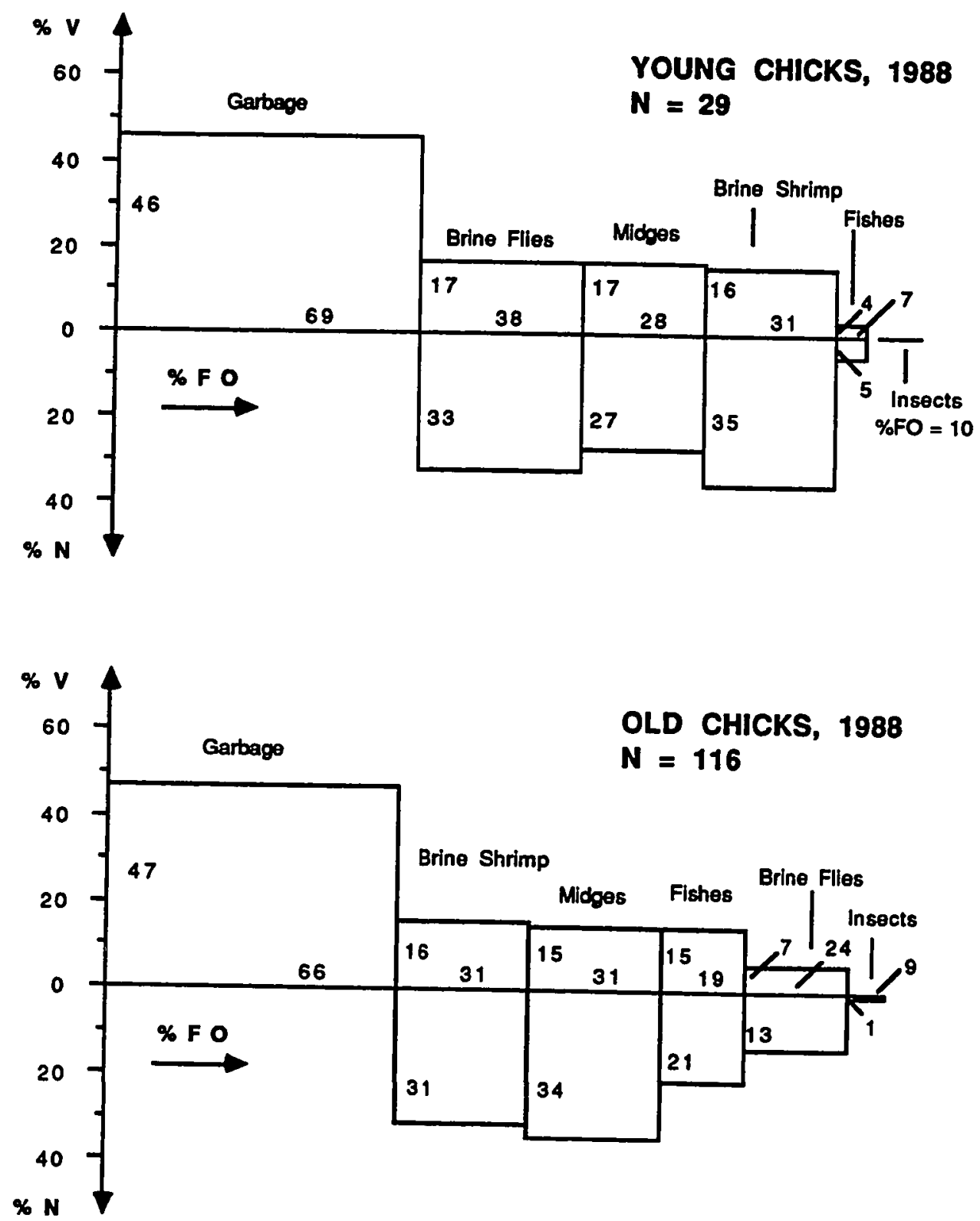

FIGURE 5. Composition of regurgitated samples from young ( $\$ 10$ days) and old ( $>10$ days) number was assigned to garbage during $\%$ Number calculations. 

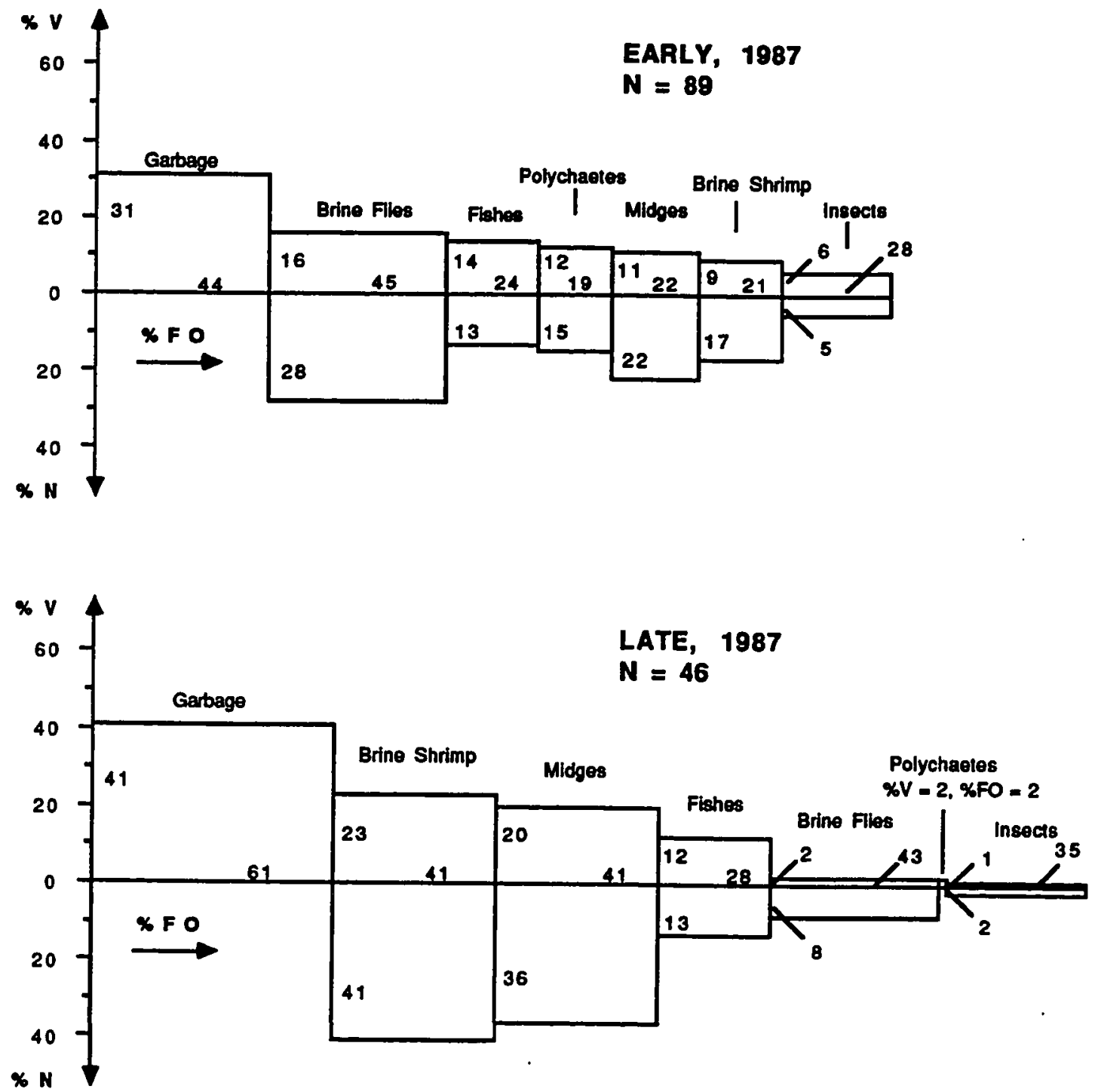

FIGURE 6. Composition of regurgitated samples from chicks early and late in the chick period (before and after June 14) in 1987 as measured by \% Volume, \% Number and $\%$ Frequency of Occurrence. No number was assigned to garbage during \% Number calculations. 

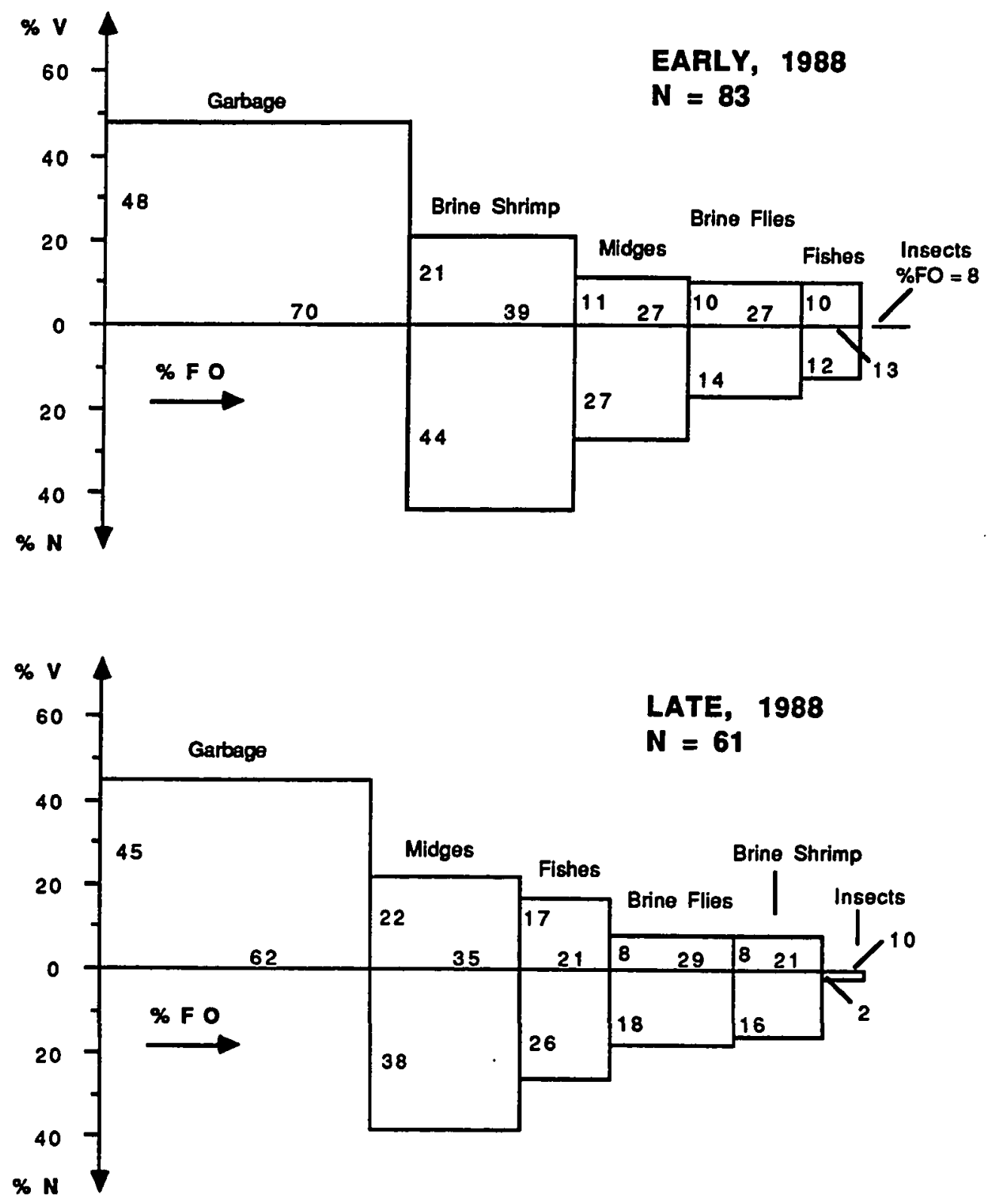

FIGURE 7. Composition of regurgitated samples from chicks early and late in the chick period (before and after June 14) in 1988 as measured by \% Volume, \% Number and $\%$ Frequency of Occurrence. No number was assigned to garbage during \% Number calculations. 

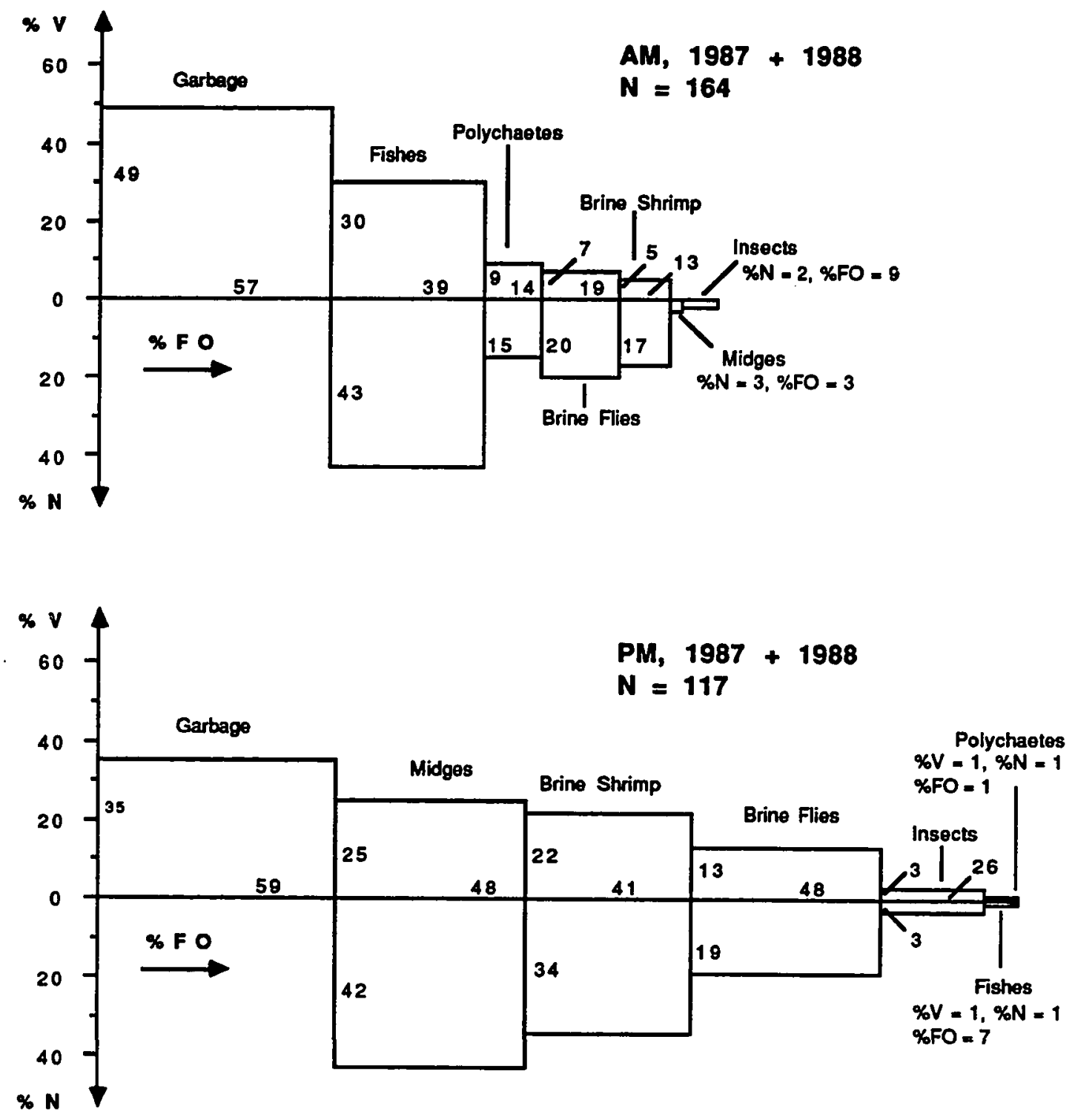

FIGURE 8. Composition of morning and evening regurgitated samples from chicks, for 1987 and 1988 combined, as measured by \% Volume, \% Number and \% Frequency of Occurrence. No number was assigned to garbage during \% Number calculations. 
a.

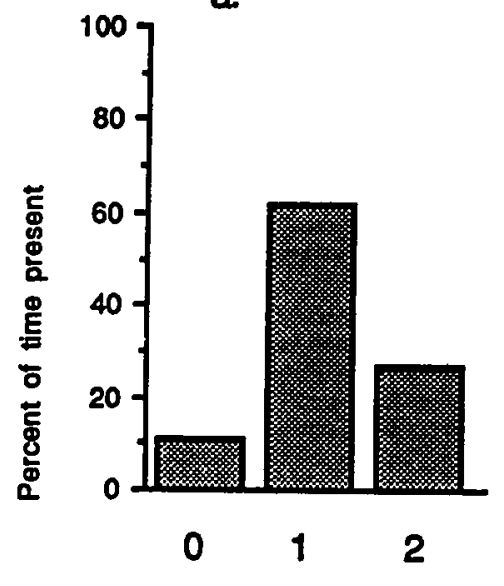

Parents/Nest b.

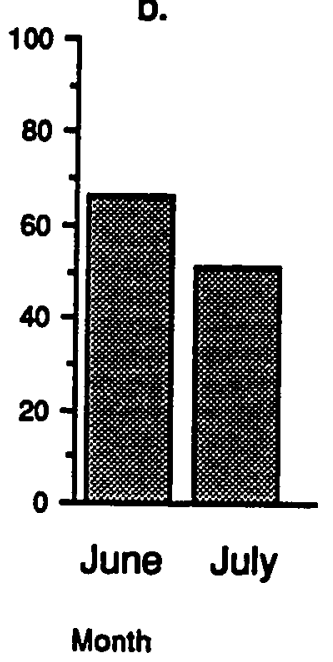

c.

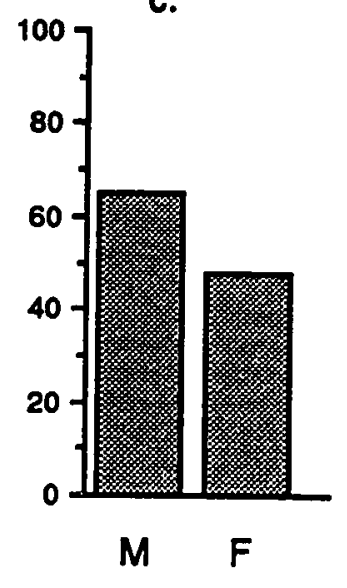

Gender of Parent

FIGURE 9. a) Mean percent of time netther, one, and both parents were present at the nest for total obsenvations ( $n=257$ nest-hrs). b) Mean percent of time nesting adults were present at the nest in June and July $\left(n=257\right.$ nest-hrs). The difference was significant $\left(x^{2}=13.226\right.$, $p<0.001)$. c) Mean percent of time males and females were present at the nest for total observations $\left(n=163\right.$ nest-hrs). The difference was significant $\left(x^{2}=9.406,0.005>p>0.001\right)$. 

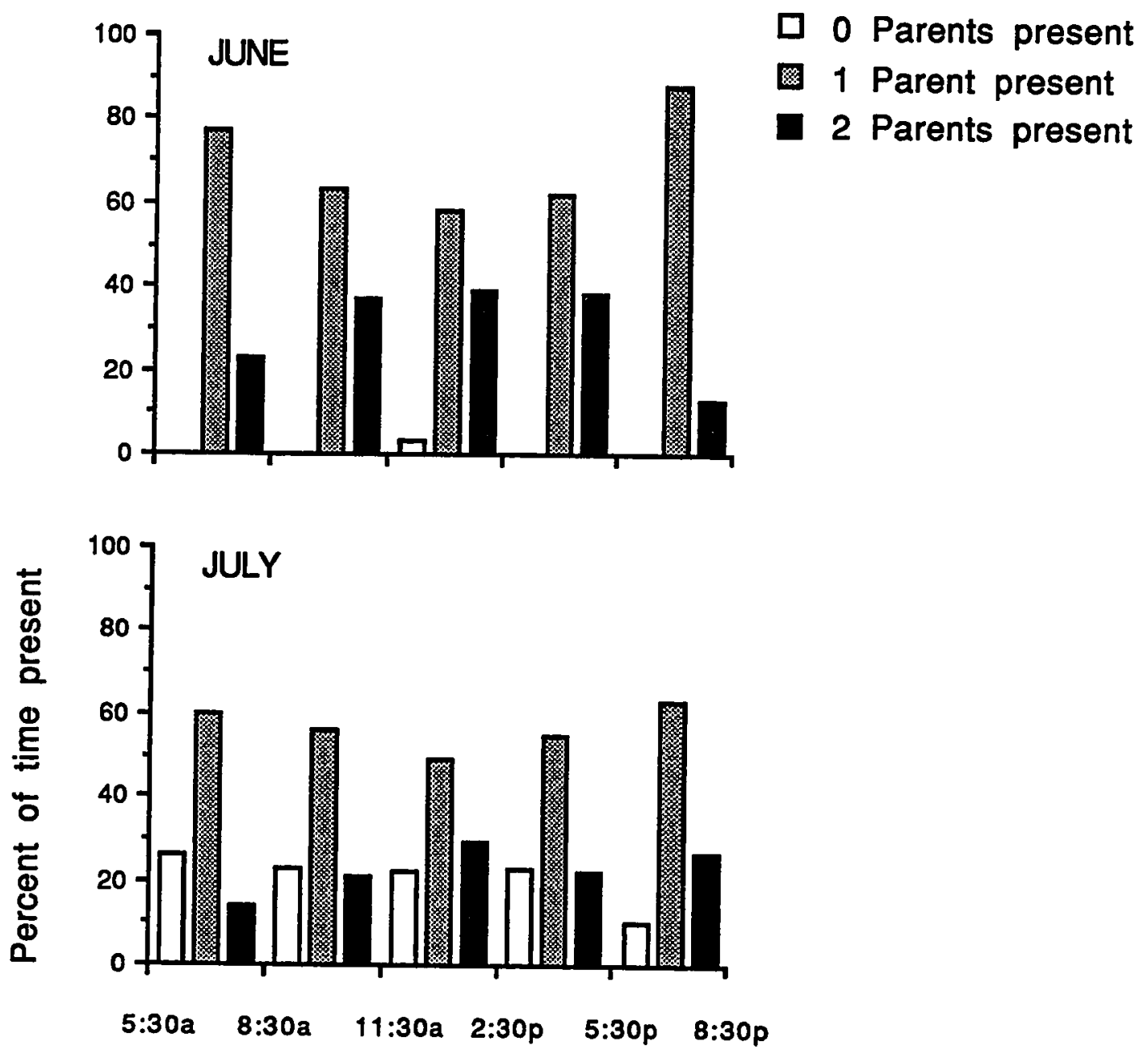

Time of day

FIGURE 10. Mean percent of time neither, one, and both parents were present at the nest for 3-hr intervais during the day in June and July ( $n=257$ nest-hrs). 